https://doi.org/10.5194/cp-2021-96

Preprint. Discussion started: 24 August 2021

(c) Author(s) 2021. CC BY 4.0 License.

1 Multiple Proxy Estimates of $\mathrm{pCO}_{2}$ in the Hauterivian-Barremian of the Laiyang Basin,

2

\title{
Eastern China
}

3 Peihong Jin ${ }^{1,2}$, Mingzheng Zhang ${ }^{1, *}$, Xiangtong Lei ${ }^{3}$, Baoxia $\mathrm{Du}^{2,4}$, Junling Dong ${ }^{5}$, Bainian Sun ${ }^{2,3}$

$4{ }^{1}$ Key Laboratory of Petroleum Resources, Northwest Institute of Eco-Environment and Resources,

5 Chinese Academy of Sciences, Gansu Province, Lanzhou 730000, China

$6 \quad{ }^{2}$ State Key Laboratory of Paleobiology and Stratigraphy, Nanjing Institute of Geology and

7 Paleontology, CAS, Nanjing 210008, China

$8{ }^{3}$ Yunnan Key Laboratory for Palaeobiology, Institute of Palaeontology, Yunnan University,

9 Yunnan Province, Kunming 650000, China

$10{ }^{4}$ School of Earth Science, Lanzhou University and Key Laboratory of Mineral Resources in

11 Western China (Gansu Province), Lanzhou 730000, China

$12{ }^{5}$ State Key Laboratory of Oil and Gas Reservoir Geology and Exploitation, Institute of Sedimentar

$13 y$ Geology, Chengdu University of Technology, Chengdu 610059, China

* Corresponding author.

E-mail address: zhangmzh08@1zb.ac.cn (M. Z. Zhang)

16 
17 Abstract: In recent decades, several proxies have been developed to reconstruct atmospheric 18 paleo- $\mathrm{CO}_{2}$ concentrations $\left(p \mathrm{CO}_{2}\right)$. The confidence in paleo- $\mathrm{CO}_{2}$ estimates can be increased by 19 comparing results from multiple proxies with multiple species at a single site. Here we present a 20 new $\mathrm{pCO}_{2}$ record for the Hauterivian-Barremian using three methods based on two fossil 21 coniferous species (Cupressinocladus sp. and Brachyphyllum obtusum) collected from Laiyang 22 Basin, eastern China. The $p \mathrm{CO}_{2}$ values were approximately 579-663 ppmv (recent standardization) 23 and 966-1106 ppmv (carboniferous standardization) based on the stomatal ratio $(S R)$-based 24 method, and about 472-525 ppmv based on the mechanistic model. Both of these two methods 25 were highly coincident with other $S R$-based and geochemical reconstructions for the early stage of 26 the Early Cretaceous. The $p \mathrm{CO}_{2}$ value estimated using the carbon isotopes model was 27 approximately $472-525$ ppmv, which is generally lower than the $p \mathrm{CO}_{2}$ valueestimated using the 28 other methods. The mechanistic model may be widely applied to more fossil taxa than the $S R$ 29 based method and retains sensitivity at high $p \mathrm{CO}_{2}$. Furthermore, by comparing with other $p \mathrm{CO}_{2}$ 30 records and Weissert event in the Early Cretaceous, the $\mathrm{pCO}_{2}$ values obtained from this study 31 indicate a relatively low atmospheric $\mathrm{CO}_{2}$ concentration during the Hauterivian-Barremian, and

32 reflect the cooling event in the last stage of the Weissert event.

34 Keywords: Hauterivian-Barremian, Cuticle, Stomatal ratio, Mechanistic model, Carbon isotope 35 model, Weissert event

\section{1. Introduction}

38 The Early Cretaceous was a critical period for the globe to enter a typical greenhouse climate 39 period in geological history. During this period, major changes occurred in the marine and 40 terrestrial environment, a large number of rift basins were formed, large igneous provinces and 41 oceanic anoxic event (OAE) frequently occurred, and the global climate fluctuated between arid 42 and humid climates (Skelton et al., 2003; Föllmi, 2012; Jenkyns, 2010). These events have greatly

43 affected the development and evolution of marine and terrestrial organisms (Skelton et al., 2003;

44 Föllmi, 2012; Jenkyns, 2010). 
47 et al., 2014). Fluctuations in atmospheric $\mathrm{CO}_{2}$ concentrations have a significant impact on the 48 carbonate saturation state in the oceans and the weathering rate of the continental surface, further 49 leading to the mass extinctions of marine and terrestrial species (Li et al., 2019). As a result, a

50 more complete understanding of atmospheric paleo- $\mathrm{CO}_{2}$ concentration $\left(p \mathrm{CO}_{2}\right)$ variations during

51 the Early Cretaceous could potentially provide us with a good reference for reconstructing the past

52 climate environment and predicting the response of climate to future elevated atmospheric $\mathrm{CO}_{2}$

53 levels.

54 In addition to early long-term atmospheric carbon cycle models (such as GEOCARB, 55 GEOCARB II, GEOCARB III, GEOCARBSULF and COPSE), several proxies have been 56 developed to reconstruct $p \mathrm{CO}_{2}$ in recent decades, including stable carbon isotopes of paleosols, 57 boron isotope $\mathrm{pH}$ derived from marine carbonate microfossils and marine alkenones, stable carbon 58 isotopes of fossil liverworts, and stomatal parameters from terrestrial vascular plant fossils 59 (Mcelwain and Chaloner, 1995; Pearson and Palmer, 2000; Beerling et al., 2001; Beerling and 60 Royer, 2002a, 2002b; Retallack, 2005; Fletcher et al., 2005; Wang et al., 2014). Among these 61 methods, the fossil plant stomatal ratio $(S R)$-based method has been widely used in $\mathrm{CO}_{2}$ estimates 62 reconstruction from Paleozoic to Cenozoic. In recent years, an increasing number of mathematical 63 models for $p \mathrm{CO}_{2}$ reconstruction have been proposed and widely used, such as the mechanistic $\mathrm{CO}_{2}$ 64 model proposed by Franks (2014) (Konrad et al., 2008; Franks et al., 2014; Konrad et al., 2017).

65 The advantage of this mechanism model is that it can be used to estimate the paleo- $\mathrm{CO}_{2}$ in any 66 period from the Devonian to the present, and it is considered to be more sensitive at high $p \mathrm{CO}_{2}$ 67 (Franks et al., 2014; Royer et al., 2019). Furthermore, with the continuous updating of the 68 methods, increasing attention has been given to the error analysis, and the requirements for the $69 p \mathrm{CO}_{2}$ reconstruction accuracy are also increasing. The $p \mathrm{CO}_{2}$ estimates based on multiple species 70 are generally thought to be more effective than the $p \mathrm{CO}_{2}$ estimates based on single species to 71 reduce the range of error (Reichgelt and D'Andrea, 2019).

In this study, we selected the well-preserved leaves of Brachyphyllum and Cupressinocladus 73 from the Lower Cretaceous of the Laiyang Basin, and used three methods: the SR-based method, 74 mechanistic model and carbon-isotope model, to reconstruct the $p \mathrm{CO}_{2}$ during the Hauterivian75 Barremian (Early Cretaceous). Moreover, a greater insight into the relationship between the $p \mathrm{CO}_{2}$ 76 concentration and the Weissert event during the Early Cretaceous is discussed. 
https://doi.org/10.5194/cp-2021-96

Preprint. Discussion started: 24 August 2021

(c) Author(s) 2021. CC BY 4.0 License.

\section{2. Material and methods}

78 2.1. Geological and stratigraphical settings

79 The Laiyang Basin refers to the Mesozoic depression in the Laiyang area of Shandong

80 Province, and this Mesozoic depression is located on the north side of the Sulu orogenic belt and

81 the east of the North China Craton (Luo et al., 1990; Li and Zhang, 2000; Jin et al., 2018; Fig. 1A,

82 B). The Cretaceous strata from this basin are well-developed, continuously exposed and complete

83 and contain abundant and various fossil categories (Luo et al., 1990; Li and Zhang, 2000; Jin et al.,

84 2018). This area is one of the most desirable areas for studying the geologic evolution of Asia in

85 the Cretaceous (Luo et al., 1990; Li and Zhang, 2000). The Laiyang Basin developed mainly the

86 Lower Cretaceous Laiyang Formation, the Qingshan Formation, and the Upper Cretaceous

87 Wangshi Formation, which do not conform to the underlying strata of the Proterozoic Jingshan

88 Group, the Archean Jiaodong Group or the overlying strata of Paleogene (Luo et al., 1990; Fig. 1A,

89 B). According to the various lithological characteristics, sedimentary cycles and fossil beds, the

90 Laiyang Formation is divided into four members (Luo et al., 1990). The third member is the main

91 fossiliferous layer of the Laiyang Formation. The total thickness of this member is 181 to 472

92 metres, and most of the area is approximately $400 \mathrm{~m}$, which is composed mainly of shale and

93 sandstone and contains small amounts of carbonate sediments (Fig. 1C). Current fossils have also

94 been collected from this member in the Huangyadi-Beibozi profile (Fig. 1C). 


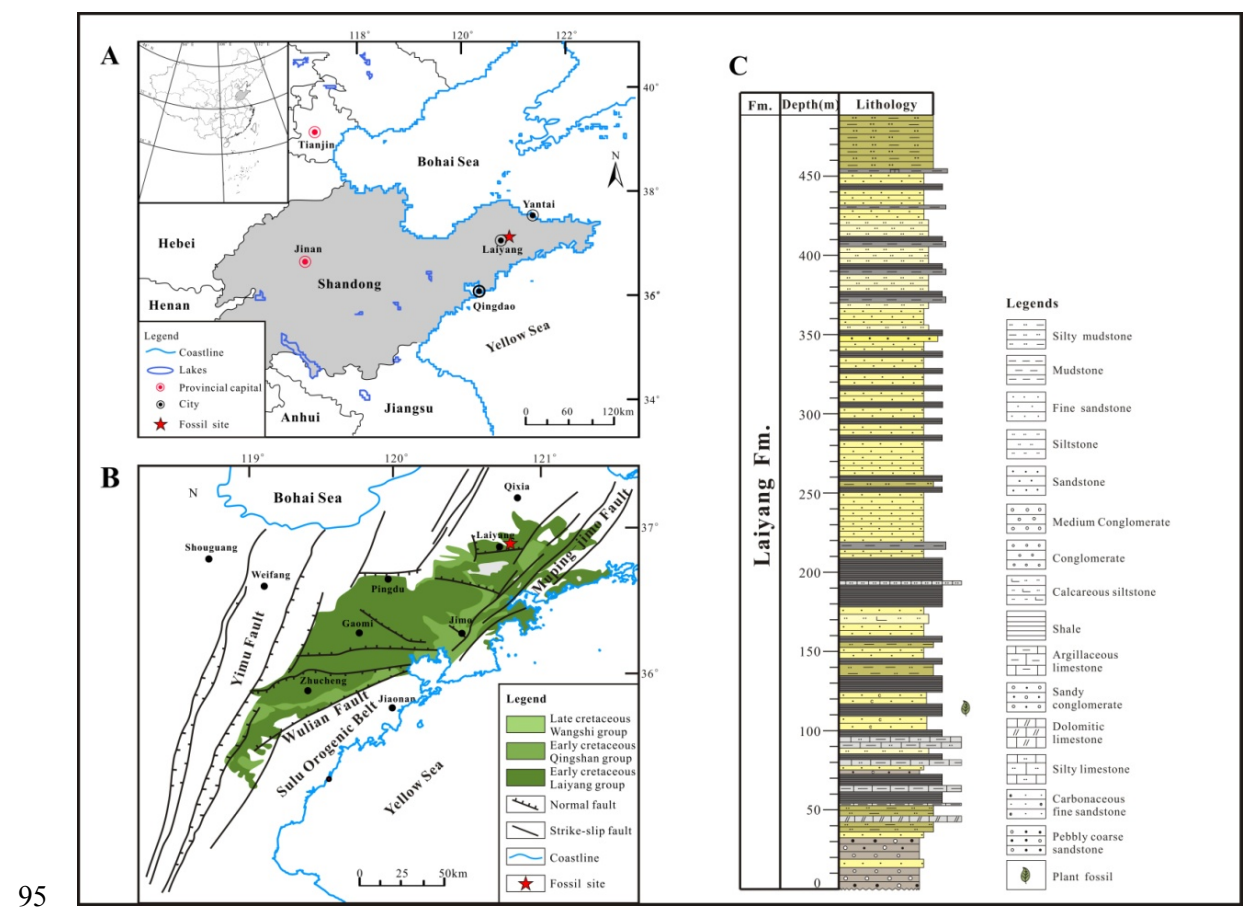

96 Fig. 1. A) Location of the fossil site and the tectonic units of the Laiyang Basin; B) Stratigraphic section of the Early Cretaceous Laiyang Formation, Laiyang Basin and the fossil-bearing horizon.

Various paleoentomologists have conducted detailed studies on the geological age of the Laiyang Formation (Luo et al., 1990; Lin, 1995; Hong, 1998; Ren and Hong, 1998; Zhang, 2003; Grimaldi and Engel, 2005; Zhang and Rasnitsyn, 2006). Now the point of view that the Laiyang Formation belongs to the Early Cretaceous has been accepted by most researchers (Chen et al., 1980; Luo et al., 1983). The significant SHRIMP U-Pb age shown by the tuff in the basal conglomerates of the Laiyang Group confirms that the age of the Laiyang Group is in the range of 120-149 Ma (Early Cretaceous) (Zhang et al., 2018). According to the ${ }^{40} \mathrm{Ar} /{ }^{39} \mathrm{Ar}$ age of hornblende and the $\mathrm{U}-\mathrm{Pb}$ dating of zircons by many researchers, the maximum deposition age of the Laiyang Formation is approximately $130 \mathrm{Ma}$ in the Hauterivian-Barremian (the early stage of the Early Cretaceous) (Ling et al., 2007; Zhang et al., 2008; Xie et al., 2012; Huo et al., 2015; O'Reilly et al., 2015). Therefore, the Laiyang Formation belongs to the Early Cretaceous, and the stratigraphic position of the current fossils is assigned to the Hauterivian-Barremian.

2.2. Fossil materials and living relatives 


\section{2.2.1 Description of the fossil species}

113 In our study, two fossil species from two plant families were recorded in the Laiyang

114 Formation in the Laiyang Basin: Brachyphyllum obtusum Chow et Tsao (family Cheirolepidiaceae)

115 and Cupressinocladus sp. (family Cupressaceae). Brachyphyllum obtusum is characterized by

116 incomplete twigs up to 3-4 $\mathrm{mm}$ wide with spirally disposed scale-like leaves (Fig. 2F-I). Leaves

117 are adpressed and imbricate, broad rhomboidal in face view, approximately $2.5-2.7 \mathrm{~mm}$ wide and

118 2-3.4 mm long (Fig. 2F-I). The leaf margin is entire, and the apex is relatively obtuse, with a

119 mucro at the top. A single midvein is prominent on the abaxial leaf surface. The leaf cuticles are

120 amphistomatic (Fig. 2F-I). The abaxial cuticle is very thick, and the stomata are arranged in

121 longitudinal rows all over the surface (Fig. 3F-I). Each row is separated by $5-10$ abaxial epidermal

122 cells. Ordinary epidermal cells are rectangular or irregular polygonal, with strongly thickened and

123 straight anticlinal walls and well-developed papillae. Stomatal complexes are rounded or narrowly

124 rounded in outline, haplocheilic and monocyclic. The guard cells are sunken and generally

125 surrounded by 4-6 subsidiary cells that form a ring. The epidermal cells and stomata of the adaxial

126 cuticle are similar to those of the abaxial cuticle. 
https://doi.org/10.5194/cp-2021-96

Preprint. Discussion started: 24 August 2021

(c) Author(s) 2021. CC BY 4.0 License.
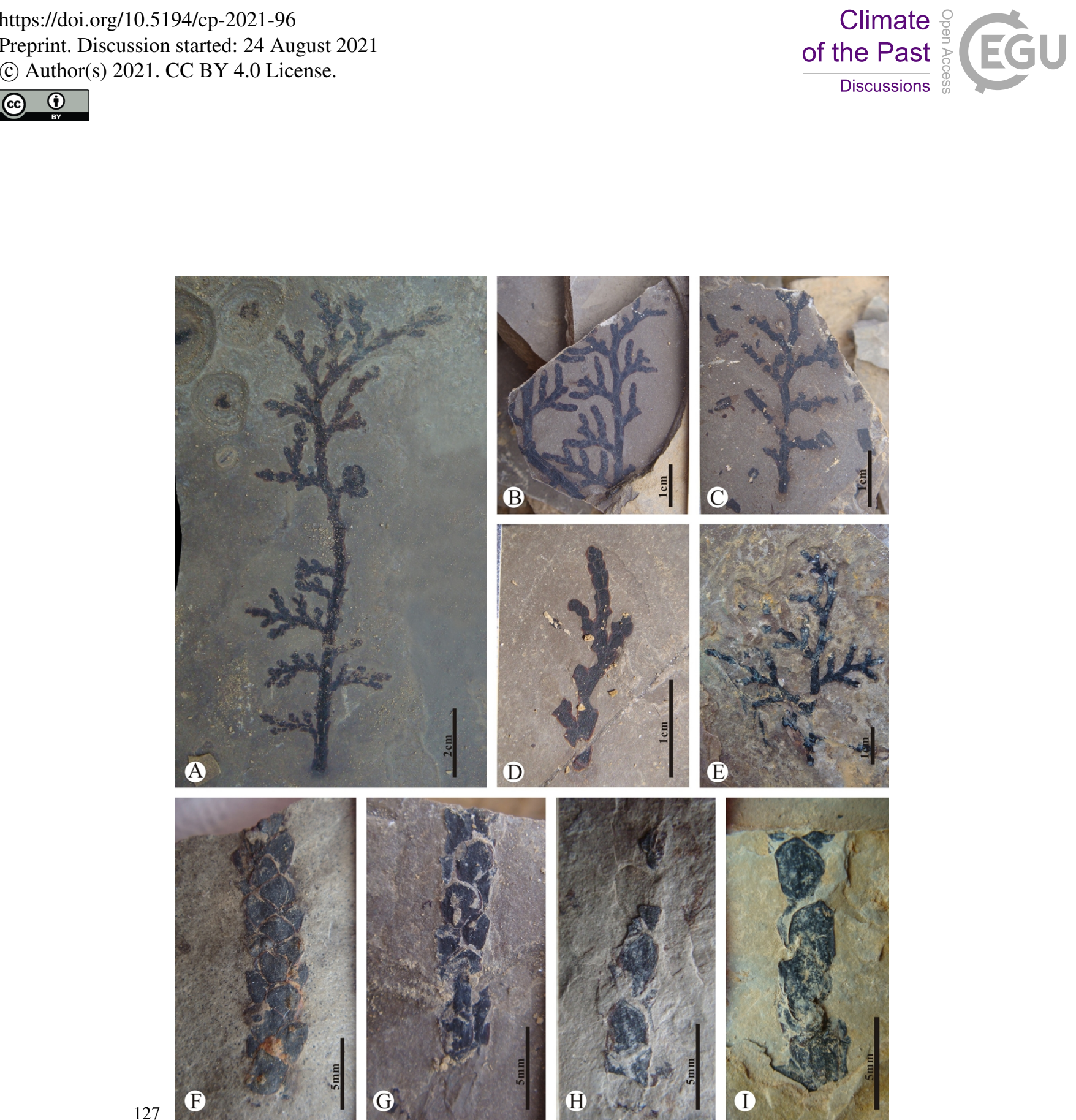

128 Fig. 2. Morphological structures of Cupressinocladus and Brachyphyllum from the Lower

129 Cretaceous of the Laiyang Basin. A-E, Cupressinocladus sp. (Specimen No: A, LDGSW-2016-

130 508A; B, LDGSW-2016-1401; C, LDGSW-2015-501A; D, LDGSW-2016-462A; E, LDGSW-

131 2015-907); F-I, Brachyphyllum obtusum (Specimen No: F, LDGSW-2015-154A; B, LDGSW-

132 2015-159B; C, LDGSW-2015-162A; D, LDGSW-2015-178A). 
https://doi.org/10.5194/cp-2021-96

Preprint. Discussion started: 24 August 2021

(c) Author(s) 2021. CC BY 4.0 License.
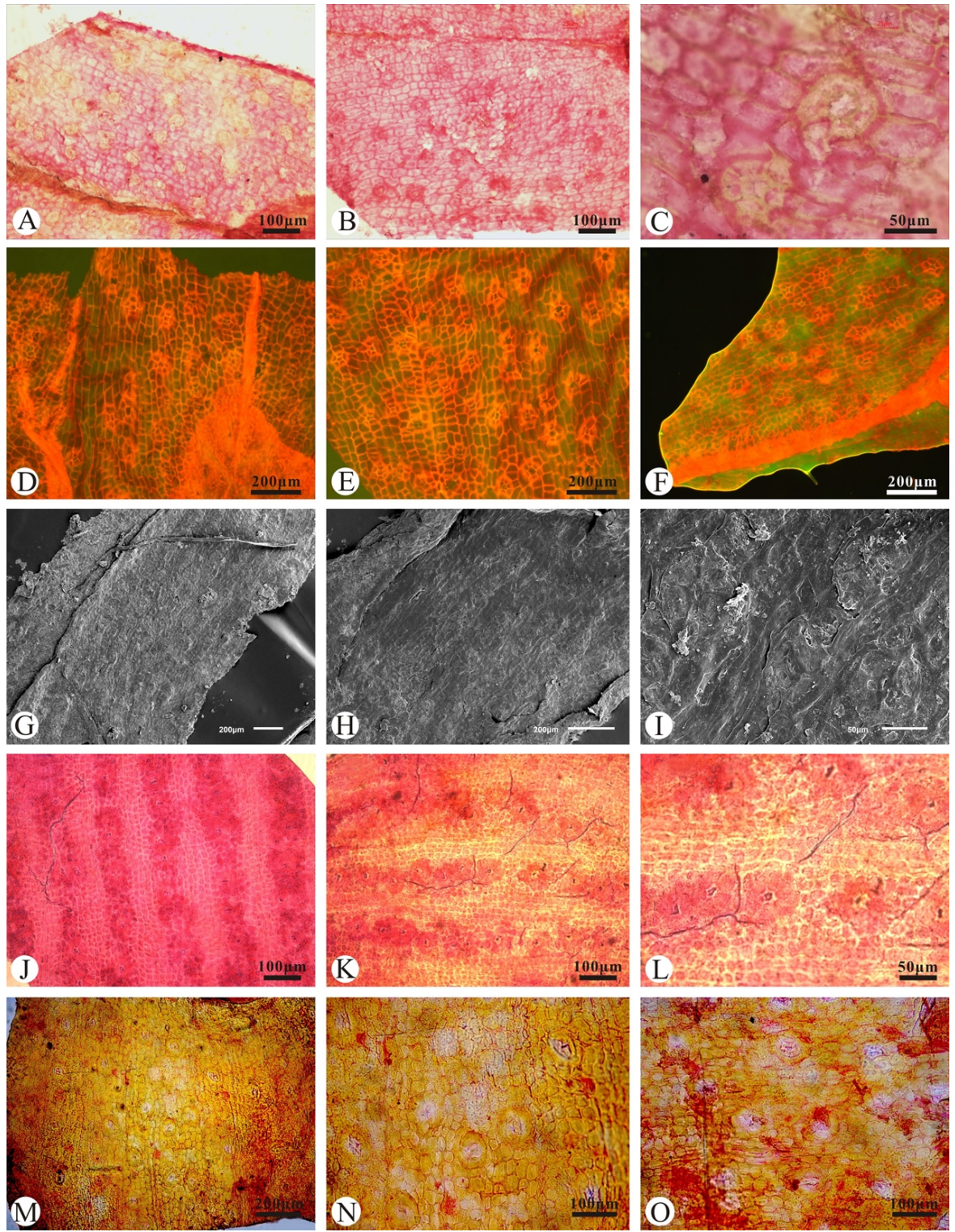

134 Fig. 3. Cuticular structures of Cupressinocladus and Brachyphyllum from the Lower Cretaceous of the Laiyang Basin. A, B, Abaxial cuticle of Cupressinocladus sp. under stereomicroscope showing epidermal cells and stomata; scale bar $100 \mu \mathrm{m}$; C, The detail of stomatal showing guard and subsidiary cells of Cupressinocladus sp. abaxial cuticle; scale bar $50 \mu \mathrm{m}$; D-F, Abaxial leaf cuticle of Cupressinocladus sp. under fluorescence microscope showing epidermal cells and stomata; scale bar $200 \mu \mathrm{m} ; \mathrm{G}, \mathrm{H}$, Adaxial cuticle of Cupressinocladus sp. under SEM showing epidermal cells and stomata; scale bar $200 \mu \mathrm{m}$; I, The detail of stomatal under SEM showing 
141 guard and subsidiary cells of Cupressinocladus sp. adaxial cuticle; scale bar $50 \mu \mathrm{m}$; J, K, Abaxial 142 cuticle of Brachyphyllum obtusum under stereomicroscope showing epidermal cells and stomata;

143 scale bar $100 \mu \mathrm{m}$; I, The detail of stomatal under stereomicroscope showing guard and subsidiary

144 cells of Brachyphyllum obtusum abaxial cuticle; scale bar $50 \mu \mathrm{m} ; \mathrm{M}-\mathrm{O}$, Adaxial cuticle of

145 Brachyphyllum obtusum under stereomicroscope showing epidermal cells and stomata; M, Scale

146 bar $200 \mu \mathrm{m}$; N, O, Scale bar $100 \mu \mathrm{m}$.

147

Cupressinocladus sp. preserved as last-second or last-third leafy twigs. The leaves on ultimate leafy shoots are sessile, decussate and imbricate arranged. The base of the leaves is decurrent and partly concealed by the leaves of the lower pair. The lateral leaves are conduplicate and oval, with the entire margin and obtuse apical tip, approximately 1.7-2.5 mm long and 0.8-1.2 $\mathrm{mm}$ wide in the exposed part. The facial leaves are rhombic at the exposed part, without keels, appressed to the shoot axis. The leaves on last-third leafy shoots are ovate to broadly lanceolate, approximately $2.3-5.2 \mathrm{~mm}$ long and $1-1.4 \mathrm{~mm}$ wide. The leaf cuticles are amphistomatic. The stomata on the adaxial cuticle are arranged in longitudinal rows all over the surface. Each row is separated by 4-6 epidermal cells, and a small number of stomata are irregularly distributed. The epidermal cells between the two bands are rectangular, with straight anticlinal walls and welldeveloped papillae, approximately $65-89 \mu \mathrm{m}$ long and $27-41 \mu \mathrm{m}$ wide. The epidermal cells in rows are short rectangular or irregular polygonal with papillae. Stomatal complexes are rounded or elliptic, haplocheilic, monocyclic. The guard cells are sunken and generally surrounded by 5-6 subsidiary cells with papillae. The abaxial cuticle epidermal cells and stomata are similar to those of the adaxial cuticle.

\subsubsection{Selection of nearest living equivalents (NLEs)}

Numerous studies have already discussed the nearest living equivalent species (NLEs) of Brachyphyllum (Cheirolepidiaceae), the most common of which are Athrotaxis cupressoides (9.0 $\pm 1.5)$, Tetraclinis articulate $(11.7 \pm 1.1)$, Calocedrus decurrens $(9.9 \pm 1.4)$, Callitris columnaris $(8.9 \pm 1.6)$, and Callitris rhomboidea $(8.2 \pm 1.4)$ as NLEs of Brachyphyllum to restore the $p \mathrm{CO}_{2}$ during the Cretaceous period (McElwain and Chaloner, 1996; Haworth et al. 2005; Haworth et al., 2010). Hence, we also selected these five species as NLEs of B. obtusum, and took their average value of $9.5 \pm 1.4$ as the stomatal index $(S I)$ of NLEs of B. obtusum.

Many leafy-shoots assignable to the Cupressinocladus have been reported from the Mesozoic strata in Europe and Asia (Florin, 1958, 1963; Harris, 1969; Miller, 1977; Shi et al., 2011; Jin et al., 2017). These leafy shoots resemble in external appearance the leafy shoots of extant Cupressaceae, but as far as their leaf-cuticle is concerned, many of the leafy shoots belong to the 
176 extinct family Cheirolepidiaceae, such as Cupressinocladus obatae and Cupressinocladus 177 ramonensis (OKUBO and KIMURA, 1991; Srinivasan, 1995). The external appearances of the 178 present species Cupressinocladus sp. is very similar to the external appearances of Cupressaceae, 179 whereas the stomata are distributed all over the surface of the leaves, and the leaves do not form 180 stomatal bands. Such stomatal distribution has also has been seen in the Cheirolepidiaceae 181 conifers. In addition, two adjacent stomata often share a single subsidiary cell in cupressaceous 182 conifers, but such characteristics have has not been observed in the present species $C$. sp. and 183 other cheirolepidiaceous conifers (except in Pseudofrenelopsis parceramosa, Glenrosa 184 pagiophylloides, Glenrosa texensis, Glenrosa falcate and Glenrosa virginiensis) (Watson, 1977; 185 Watson and Fisher, 1984; Srinivasan, 1992; Gomez et al., 2012). To date, as far as the cuticular 186 features mentioned above are concerned, the present species more resembles to Cheirolepidiacea.

187 Based on the similarities of ecology and morphology, the extant Athrotaxis cupressoides, 188 Tetraclinis articulate, Calocedrus decurrens, Callitris columnaris, Callitris rhomboidea and 189 Salicornia virginica have been selected as the NLEs of the extinct Cheirolepidiaceae conifers by 190 numerous researchers (McElwain and Chaloner, 1996; Haworth et al. 2005; Haworth et al., 2010).

191 Among these conifers, Tetraclinis articulate, Calocedrus decurrens, Callitris columnaris, Callitris

192 rhomboidea also belong to Cupressaceae, and the external appearance of these four speciesis are

193 similar to the external appearance of the present leafy-shoots. Therefore, we select these four 194 species as NLEs of $C$. sp., and take their average value $9.7 \pm 1.5$ as the SI of NLEs of $C$. sp..

196 2.3. Proxy models and methods

197 2.3.1 SR-based method

McElwain and Chaloner (1995) proposed the SR-based method and the conception of "the 199 nearest living equivalent (NLE)". NLE refers to the living species that share similar 200 ecoenvironments and functional structures with fossil plants (McElwain, 1998; Chen et al., 2001).

201 NLE is applied mainly in the comparison of the stomatal parameters between living and fossil 202 plants and then to reconstruct the $\mathrm{pCO}_{2}$ semiquantitatively (McElwain, 1998; Chen et al., 2001). 203 Four parameters need to be calculated when using $S R$-based method in $p \mathrm{CO}_{2}$ reconstruction: stomatal density $(S D)$, epidermal density $(E D), S I$ and $S R$, and detailed descriptions of all the parameters and equations involved are listed in Table 1. This method was standardized by 206 McElwain and Chaloner (1996) and McElwain (1998) with two standardizations: carboniferous standardization $\left(1 \mathrm{~S} R=2 R \mathrm{CO}_{2}\right)$ and recent standardization $\left(1 \mathrm{SR}=1.2 R \mathrm{CO}_{2}\right)$. Carboniferous

208 standardization has been found to be most appropriate for $p \mathrm{CO}_{2}$ reconstruction based on the Paleozoic and Mesozoic taxa, whereas recent standardization is more applicable to the $p \mathrm{CO}_{2}$ 
210 reconstruction of Cenozoic taxa (Steinthorsdottir et al., 2011; Steinthorsdottir et al., 2013;

211 Steinthorsdottir and Vajda, 2015). Here, we used both standardizations to obtain the minimum and

212 maximum paleo- $\mathrm{CO}_{2}$ estimates. The relation between $p \mathrm{CO}_{2}$ and stomatal parameters can be

213 expressed by the equation $p \mathrm{CO}_{2}(\mathrm{ppmv})=S R \times 300$.

214 Table 1 Parameters required by the SR-based method.

\begin{tabular}{lll}
\hline Parameter & Unit & Description \\
\hline$S D$ & $\mathrm{~mm}^{-2}$ & Stomatal density, the number of stomata in unit area $\left(\mathrm{mm}^{2}\right)$ \\
$E D$ & $\mathrm{~mm}^{-2}$ & $\begin{array}{l}\text { Epidermal density, the number of epidermic cells in unit area }\left(\mathrm{mm}^{2}\right) \\
\text { Stomatal index, the percentage of stomata to the total number of stomata } \\
\text { and epidermal cells, } S I=S D /(S D+E D) \times 100\end{array}$ \\
& $\%$ & $\begin{array}{l}\text { Stomatal ratio, the stomata index ratio between the NLEs and fossil } \\
\text { species, } S R=S I_{N L E s} / S I_{\text {fossil }}\end{array}$ \\
$S R$ & - & The stomatal index of the NLEs \\
$S I_{N L E s}$ & $\%$ & The stomatal index of the fossil species \\
$S I_{\text {fossil }}$ & $\%$ & The ratio of the paleo-CO $\mathrm{CO}_{2}$ concentration over the pre-industrial \\
$R \mathrm{CO}_{2}$ & - & revolution level (approximately 300 ppmv) \\
\end{tabular}

218 2.3.2 The mechanistic model

219 Recently, the mechanistic model based on leaf gas exchange has been widely applied to 220 obtain the $\mathrm{PCO}_{2}$ during the Mesozoic and Paleozoic (Konrad et al., 2008; Franks et al., 2013; 221 Franks et al., 2014; Konrad et al., 2017; Du et al., 2018; Li et al., 2019; Zhou et al., 2020). The precondition of mechanistic model is to assume that the exchange conditions and forms of gases in the photosynthesis of the ancient forest are the same as those of the living forest (Franks et al. 2014). The change in paleoatmospheric $\mathrm{CO}_{2}$ concentration $\left(C_{a}\right)$ would influence the diffusion rate of the $\mathrm{CO}_{2}$ from the atmosphere to the fixation part (stomata) in the leaf (Franks et al. 2014). In turn, the diffusion rate influences the $\mathrm{CO}_{2}$ assimilation rate $\left(A_{n}\right)$ in organisms (Franks et al. 2014). This mechanistic model estimates the concentration of atmospheric $\mathrm{CO}_{2}$ by iteratively solving the equations (1)-(7) in Fig.4 based on three parameters, including $A_{n}$ (the assimilation rate of plant leaves towards $\mathrm{CO}_{2}$, which can be calculated by estimating $A_{0}$ ), $g_{c(t o t)}$ (the total operational conductance to $\mathrm{CO}_{2}$ diffusion) and $C_{i} / C_{a}$ (the ratio of leaf internal $\mathrm{CO}_{2}$ concentration to $C_{a}$ )

231 (Farquhar et al., 1980; Farquhar et al., 1982; Farquhar et al., 1989; Franks et al., 2009; Franks et al.

232 2013; Franks et al. 2014). 


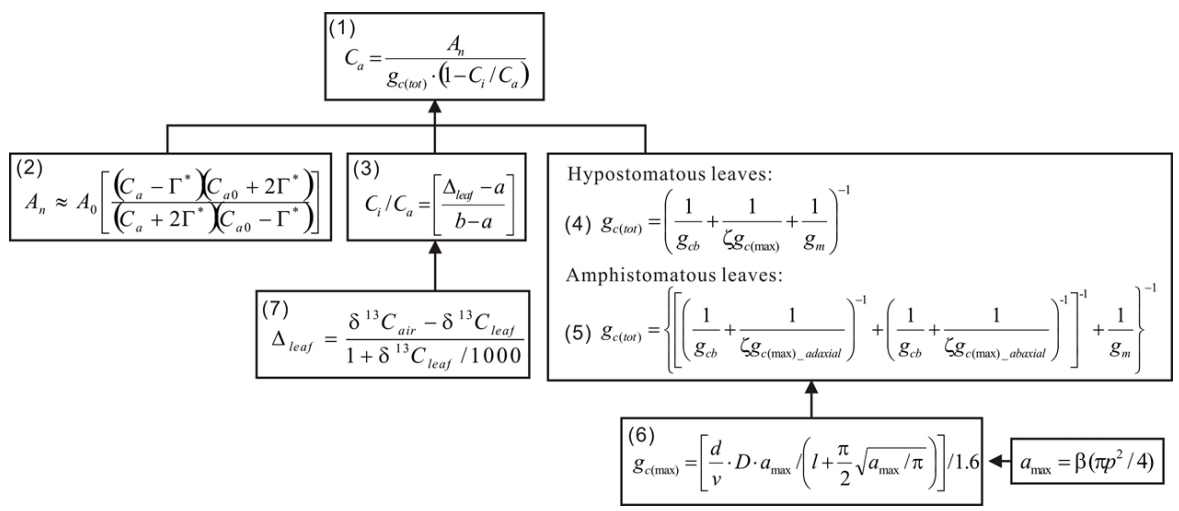

234 Fig. 4. The main equation and procedures of the mechanistic model based on Franks et al. (2014).

235 All parameters and their description are listed on Table 2.

237 Table 2 Parameters required by the mechanistic model based on Franks et al. (2014)

\begin{tabular}{|c|c|c|}
\hline Parameter & Unit & Description \\
\hline$C_{i}$ & $\mathrm{~mol} \mathrm{~m}^{-3}$ & Leaf internal $\mathrm{CO}_{2}$ \\
\hline$C_{a}$ & $\operatorname{ppmv}\left(\mathrm{mol} \mathrm{m}^{-3}\right)$ & Atmospheric $\mathrm{CO}_{2}$ \\
\hline$A_{n}$ & $\mu \mathrm{mol} \mathrm{m}{ }^{-2} \mathrm{~s}^{-1}$ & The $\mathrm{CO}_{2}$ assimilation rate \\
\hline$g_{c(t o t)}$ & $\mathrm{mol} \mathrm{m}^{-2} \mathrm{~s}^{-1}$ & The total operational conductance to $\mathrm{CO}_{2}$ diffusion \\
\hline$g_{c b}$ & $\mathrm{~mol} \mathrm{~m}^{-2} \mathrm{~s}^{-1}$ & $\begin{array}{l}\text { Leaf boundary layer conductance to } \mathrm{CO}_{2}, 2.0 \mathrm{~mol} \mathrm{~m}^{-2} \mathrm{~s}^{-1} \\
\text { (Collate et al., 1991) }\end{array}$ \\
\hline$g_{c(o p)}$ & $\mathrm{mol} \mathrm{m}^{-2} \mathrm{~s}^{-1}$ & Operational stomatal conductance \\
\hline$g_{m}$ & $\mathrm{~mol} \mathrm{~m}^{-2} \mathrm{~s}^{-1}$ & $\begin{array}{l}\text { The mesophyll conductance, derived from Epron et al. 1995, } \\
\text { Evans and Von Caemmerer, } 1996\end{array}$ \\
\hline$g_{c(\max )}$ & $\mathrm{mol} \mathrm{m}^{-2} \mathrm{~s}^{-1}$ & The Maximum of $g_{c(o p)}$ (When the stomata opening is the largest) \\
\hline$\zeta$ & - & $\begin{array}{l}\text { The ratio of operational stomatal conductance to maximum } \\
\text { stomatal conductance, } 0.2 \text { (Franks et al., 2009) }\end{array}$ \\
\hline$a_{\max }$ & $\mathrm{m}^{2}$ & Maximum area of stomatal pore for maximally open stoma \\
\hline$l$ & $\mu \mathrm{m}$ & Stomatal pore depth \\
\hline$p$ & $\mu \mathrm{m}$ & Stomatal pore length \\
\hline$d / v$ & $\mathrm{~mol} \mathrm{~m}^{-1} \mathrm{~s}^{-1}$ & $\begin{array}{l}\text { The ratio of diffusivity of } \mathrm{CO}_{2} \text { in air to molar volume of air, } \\
9.40096 \times 10^{-5} \mathrm{~mol} \mathrm{~m}^{-1} \mathrm{~s}^{-1} \text { (Franks and Beerling, 2009) }\end{array}$ \\
\hline$S D$ & $\mathrm{~mm}^{-2}$ & Stomatal density \\
\hline$\beta$ & - & $\begin{array}{l}\text { Maximum pore area/area of circle with diameter, } 0.5 \text { (Franks et } \\
\text { al., 2014) }\end{array}$ \\
\hline$\delta^{13} C_{\text {leaf }}$ & $\%$ & $\begin{array}{l}\text { Carbon isotope composition of fossil leaves, measurements on } \\
\text { fossil leaves }\end{array}$ \\
\hline$\delta^{13} C_{\text {air }}$ & $\%$ & Carbon isotope composition of palaeoatmosphere \\
\hline$\Delta_{\text {leaf }}$ & $\%$ & The carbon isotope discrimination by the plant \\
\hline$a$ & $\%$ & $\begin{array}{l}\text { The carbon isotope fractionation due to diffusion of } \mathrm{CO}_{2} \text { in air, } \\
4.4 \% \text { (Von Caemmerer, 2000) }\end{array}$ \\
\hline
\end{tabular}




\begin{tabular}{|c|c|c|}
\hline$b$ & $\%$ & $\begin{array}{l}\text { The fractionation associated with RuBP carboxylase, } 30 \% \text { (Von } \\
\text { Caemmerer, 2000) }\end{array}$ \\
\hline$A_{0}$ & $\mu \mathrm{mol} \mathrm{m}{ }^{-2} \mathrm{~s}^{-1}$ & 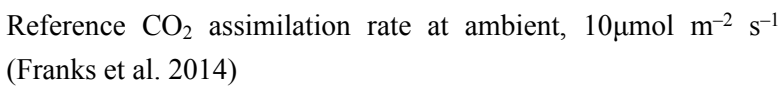 \\
\hline$C_{a 0}$ & ppmv & $\begin{array}{l}\text { Assigned to correspond approximately with } A_{0}, 360 \mathrm{ppmv} \\
\text { (Franks et al., 2014) }\end{array}$ \\
\hline$\Gamma^{*}$ & $\mu \mathrm{mol} \mathrm{mol}{ }^{-1}$ & $\begin{array}{l}\mathrm{CO}_{2} \text { compensation point in the absence of dark respiration, } 40 \\
\mu \mathrm{mol} \mathrm{mol}{ }^{-1}\left(25^{\circ} \mathrm{C}\right) \text { (Franks et al., 2014) }\end{array}$ \\
\hline
\end{tabular}
regeneration-limited photosynthesis (Farquhar et al., 1980). In this equation, $A_{0}$ and $C_{a 0}$ are the 242 reference values of $A_{n}$ and $C_{a}$ of the four groups under general environmental conditions. The 243 plants analysed in this paper all belong to the conifer group. Therefore, $A_{0}$ and $C_{a 0}$ take values of $24410 \mu \mathrm{mol} \mathrm{m}^{-2} \mathrm{~s}^{-1}$ and $360 \mathrm{ppmv}$ respectively (Franks et al. 2014). $g_{c(t o t)}$ is composed of three main 245 components: $g_{c b}\left(2 \mathrm{~mol}^{-1} \mathrm{~s}^{-1}\right), g_{c(\max )}$ and $g_{m}$. For trees that grow naturally under external conditions, 246 the $\zeta$ value is usually approximately 0.2 . Equation (4) is the standard form for $g_{c(t o t)}$ of 247 hypostomatous leaves (Franks et al. 2014). For amphistomatous leaves the term $\left(\left(1 / \mathrm{g}_{\mathrm{cb}}\right)+\right.$ $\left.248\left(1 / \zeta \mathrm{g}_{\mathrm{c}(\max )}\right)\right)^{-1}$ must be calculated separately for the adaxial and abaxial leaf surfaces $\left(g_{c(\max ) \text { adaxial }}\right.$ 249 and $g_{c(\max )_{a} a b a x i a l}$ are the maximum stomatal conductance to $\mathrm{CO}_{2}$ of the adaxial and abaxial leaf 250 surfaces, respectively), added together in parallel, and then added in series with $g_{m}$ to obtain $g_{c}($ tot) 251 (equation (5); Franks et al. 2014; Fig.4). $g_{c(\max )}$ is obtained by basic diffusion equations (6) by 252 measuring $l$ (stomatal pore depth) and $S D$ (stomatal density) of the fossil plant. $a_{\max }$ determines the 253 length of the stomatal pore $(p): a_{\max }=\beta\left(\pi p^{2} / 4\right)$, in which the $\beta$ values of pteridophytes and 254 gymnosperms are usually 0.5 (Franks et al., 2014). $C_{i} / C_{a}$ can be obtained by measuring the relative 255 carbon isotope composition of the fossil leaves $\left(\delta^{13} C_{\text {leaf }}\right)$ (see equations (3) and (7)). In equation 256 (7), $\Delta_{\text {leaf }}(\%)$ can be obtained by the analysis of $\delta^{13} C_{\text {leaf }}$ and translation of $\delta^{13} C_{\text {air }}$, both of which 257 were introduced later in this study.

258 This model has been described and discussed in detail by Franks et al. (2014). Thus, only a 259 brief introduction is presented here, and detailed descriptions of all the parameters involved are 260 listed in Table 2. The calculation of $\mathrm{Ca}\left(\mathrm{pCO}_{2}\right)$ and other variables was performed by the $\mathrm{R}$ 261 program, which was provided by Franks et al. (2014).

\section{2.3.3 Carbon isotope model}

264 Carbon isotopes of plant fossils are relevant tools for describing past carbon cycle and $265 \mathrm{CO}_{2}$ dynamics (Schubert and Jahren, 2012; Franks et al., 2014; Barral et al., 2017b; Barral et al., 266 2017a). Atmospheric $\mathrm{CO}_{2}$ is the main source of carbon assimilated by plants via photosynthesis 
267 (Barral et al., 2017a). These theories make it possible to use the carbon isotope composition of 268 plant fossils to analyse the evolution of atmospheric $p \mathrm{CO}_{2}$ during past periods. Schubert and 269 Jahren (2012) established a carbon isotope model (equation (8), r=0.9) relating $p \mathrm{CO}_{2}$ to $\delta^{13} C_{\text {leaf }}$ to 270 reconstruct the $p \mathrm{CO}_{2}$ concentration.

$$
\Delta^{13} C_{\text {leaf }}=\frac{(28.26)(0.22)\left(\mathrm{pCO}_{2}+23.9\right)}{28.26+(0.22)\left(\mathrm{pCO}_{2}+23.9\right)}
$$
concomitant $\delta^{13} C_{\mathrm{CO} 2}$ values by using equation (9) (Farquhar et al., 1982).

$$
\Delta^{13} C_{\text {leaf }}=\frac{\delta^{13} C_{\mathrm{CO}_{2}}-\delta^{13} C_{\text {leaf }}}{1+\delta^{13} C_{\text {leaf }} / 1000}
$$

276 Where $\delta^{13} C_{\text {leaf }}$ is the carbon isotope composition of leaves of fossil plants and $\delta^{13} C_{\mathrm{CO} 2}$ is the carbon isotope composition of atmospheric $\mathrm{CO}_{2}$ during the geological period (Farquhar et al., 1982). The $\delta^{13} C_{\mathrm{CO} 2}$ during the Hauterivian-Barremian is taken as an average value of $-5.78 \%$ in this paper, which is based on the $\delta^{13} C_{C O 2}$ reconstructed by Barral et al (2017a) from the carbon

280 isotope value of marine carbonate.

\subsubsection{Fossil cuticle proxy measurements}

The fossil cuticles were removed from rock using tweezers and a needle and then immersed in a $10 \%$ hydrochloric acid $(\mathrm{HCl})$ solution for $24 \mathrm{~h}$. After being washed a few times with distilled water, the cuticle samples were immersed in a 50\% hydrofluoric acid (HF) solution for $24 \mathrm{~h}$ and then treated with Schulze solution for a few minutes to hours until the cuticle turned yellow and translucent. The abaxial and adaxial cuticles were separated using a needle under a dissection microscope. The isolated cuticles were washed with distilled water and gently brushed several times until the cuticle was clean. Some cuticle samples were mounted on slides, embedded in glycerin jelly, and sealed with Canadian balsam. The cuticle slides were observed under a Zeiss AXO-40 microscope, and some cuticle samples were mounted on stubs, coated with gold and examined under an SEM (scanning electron microscope, JEOL JSM-5600LV) at Lanzhou University, China.

We used 16 cuticle samples of Cupressinocladus sp. and 14 cuticle samples of B. obtusum (120 samples in total) for paleo- $\mathrm{CO}_{2}$ analysis. All cuticle parameters (e.g. stomatal density,

296 stomatal index, stomatal/pore length, stomatal width) were counted within $0.09 \mathrm{~mm}_{2}$ squares, and

297 Photoshop CS8 software was used for at least 5 counts for each specimen. All leaf-level 298 measurements and paleo- $\mathrm{CO}_{2}$ estimates are presented Table 3-5. For each proxy method, 95\% confidence intervals for estimated $\mathrm{CO}_{2}$ were determined using 10,000 Monte Carlo simulations 
300 (Table 3-5, Fig. 6) to propagate uncertainties in all input parameters.

301 The carbon stable isotopes were measured at Key Laboratory of Petroleum Resources, 302 Northwest Institute of Eco-Environment and Resources, Chinese Academy of Sciences (Lanzhou, 303 China). The fossil leaf samples were removed and treated with $10 \% \mathrm{HCl}$ for $24 \mathrm{~h}$ and then washed 304 multiple times with distilled water until neutral. Next the fossil leaf samples were treated with $50 \%$ $305 \mathrm{HF}$ for $24 \mathrm{~h}$ and rinsed again. Finally, the fossil leaf samples were dried in a drying oven at $40{ }^{\circ} \mathrm{C}$ 306 for $24 \mathrm{~h}$, and their $\delta^{13} C_{\text {leaf }}$ was measured with a Flash 2000 HT Elemental Analyser connected to a 307 Thermo Fisher MAT-253 mass spectrometer. The fossil leaf samples were normalized to the Pee 308 Dee Belemnite (PDB) standard with an analysis precision of $\pm 0.3 \%$, using IAEA- 600 caffeine as 309 a certified reference material. The carbon isotopic composition of atmospheric $\mathrm{CO}_{2}\left(\delta^{13} C_{\text {air }}\right)$ 310 (which was used in the Franks' model) is obtained by $\delta^{13} C_{\text {leaf }}$ from the equation $\delta^{13} C_{\text {air }}=\left(\delta^{13} C_{\text {leaf }}\right.$ $311+18.67) / 1.10$ (Arens et al., 2000).

\section{4. Results and Discussion}

314 4.1. Results and comparison across methods

The $p \mathrm{CO}_{2}$ in the Laiyang Basin during the Hauterivian-Barremian was reconstructed by two 316 fossil coniferous species (Cupressinocladus sp. and Brachyphyllum obtusum) based on the SR 317 method, mechanistic model and carbon isotope model. Using the $S R$-based method, the $S I$ and $S R$ 318 values of our fossil specimens were measured and calculated, and the estimated $p \mathrm{CO}_{2}$ results were 319 in the range of 579 to $663 \mathrm{ppmv}$ based on recent standardization and between 966 and $1106 \mathrm{ppmv}$ 320 based on carboniferous standardization (Table 3; Fig. 5A). Using the mechanistic model, the mean 321 results of $p \mathrm{CO}_{2}$ ranged from 472 to $525 \mathrm{ppmv}$, which is lower than the estimated results based on 322 the $S R$-based method (Table 4; Fig. 5A). The carbon isotope model contributed the lowest value of $323 p \mathrm{CO}_{2}$, which ranged from 202 to 409 ppmv (Table 5; Fig. 5A). 
324 Table 3 Stomatal parameters of Brachyphyllum and Cupressinocladus from Laiyang Basin 325 during Hauterivian-Barremian, and estimated $p \mathrm{CO}_{2}$ values based on the SR-based method.

\begin{tabular}{|c|c|c|c|c|c|c|c|c|c|}
\hline \multirow[t]{2}{*}{ Taxon } & \multirow[t]{2}{*}{$\begin{array}{l}\text { Specimen } \\
\text { number }\end{array}$} & \multirow[t]{2}{*}{$\begin{array}{l}E D \\
\left(\mathrm{~mm}^{-2}\right)\end{array}$} & \multirow{2}{*}{$\begin{array}{l}S D \\
\left(\mathrm{~mm}^{-}\right. \\
\left.{ }^{2}\right)\end{array}$} & \multirow[t]{2}{*}{$\begin{array}{l}S I \\
(\%)\end{array}$} & \multirow[t]{2}{*}{$S R$} & \multicolumn{2}{|c|}{$\begin{array}{l}\text { Carboniferous } \\
\text { standardization }\end{array}$} & \multicolumn{2}{|c|}{$\begin{array}{l}\text { Recent } \\
\text { standardization }\end{array}$} \\
\hline & & & & & & $\begin{array}{l}\mathrm{RCO} \\
2 \\
\end{array}$ & $\begin{array}{l}p \mathrm{CO}_{2} \\
(\mathrm{ppmv})\end{array}$ & $\mathrm{RCO}_{2}$ & $\begin{array}{l}p \mathrm{CO}_{2} \\
\text { (ppmv) }\end{array}$ \\
\hline Cupressino & LDGSW- & 1619.6 & 94.6 & 5.5 & 1.8 & 3.5 & 1054.4 & 2.1 & 632.7 \\
\hline \multirow[t]{17}{*}{ cladus sp. } & 2016-508A & 1418.9 & 77.0 & 5.1 & 1.9 & 3.8 & 1131.3 & 2.3 & 678.8 \\
\hline & & 1598.7 & 86.6 & 5.1 & 1.9 & 3.8 & 1132.7 & 2.3 & 679.6 \\
\hline & & 1591.8 & 86.4 & 5.1 & 1.9 & 3.8 & 1130.3 & 2.3 & 678.2 \\
\hline & LDGSW- & 1316.2 & 65.0 & 4.7 & 2.1 & 4.1 & 1236.8 & 2.5 & 742.1 \\
\hline & $2016-462 \mathrm{~A}$ & 1211.5 & 68.4 & 5.3 & 1.8 & 3.6 & 1088.7 & 2.2 & 653.2 \\
\hline & & 1871.2 & 96.0 & 4.9 & 2.0 & 4.0 & 1193.1 & 2.4 & 715.9 \\
\hline & LDGSW- & 2515.0 & 124.3 & 4.7 & 2.1 & 4.1 & 1235.6 & 2.5 & 741.4 \\
\hline & 2016-1401 & 2477.4 & 126.6 & 4.9 & 2.0 & 4.0 & 1196.7 & 2.4 & 718.0 \\
\hline & & 2384.2 & 118.6 & 4.7 & 2.0 & 4.1 & 1228.3 & 2.5 & 737.0 \\
\hline & & 2019.0 & 110.9 & 5.2 & 1.9 & 3.7 & 1117.4 & 2.2 & 670.5 \\
\hline & $\begin{array}{l}\text { LDGSW- } \\
\text { 2015-487A }\end{array}$ & 1613.7 & 92.8 & 5.4 & 1.8 & 3.6 & 1070.4 & 2.1 & 642.2 \\
\hline & $\begin{array}{l}\text { LDGSW- } \\
\text { 2015-501A }\end{array}$ & 1213.5 & 85.6 & 6.6 & 1.5 & 2.9 & 883.0 & 1.8 & 529.8 \\
\hline & LDGSW- & 1009.1 & 59.8 & 5.6 & 1.7 & 3.5 & 1040.3 & 2.1 & 624.2 \\
\hline & 2015-907 & 1114.5 & 76.4 & 6.4 & 1.5 & 3.0 & 907.3 & 1.8 & 544.4 \\
\hline & & 1978.2 & 116.6 & 5.6 & 1.7 & 3.5 & 1045.2 & 2.1 & 627.1 \\
\hline & Average & 1684.5 & 92.9 & $5.3 \pm$ & $1.8 \pm$ & $3.7 \pm$ & 1105.7 & $2.2 \pm 0$ & 663.4 \\
\hline & value & \pm 216.0 & \pm 9.5 & 0.2 & 0.1 & 0.2 & \pm 47.4 & 1 & \pm 28.4 \\
\hline Brachyphyll & LDGSW- & 1878.8 & 112.7 & 5.7 & 1.7 & 3.4 & 1007.0 & 2.0 & 604.2 \\
\hline \multirow[t]{14}{*}{ um obtusum } & $2016-162 \mathrm{~A}$ & 1847.8 & 105.6 & 5.4 & 1.8 & 3.5 & 1054.5 & 2.1 & 632.7 \\
\hline & LDGSW- & 1414.6 & 79.2 & 5.3 & 1.8 & 3.6 & 1074.9 & 2.1 & 644.9 \\
\hline & $2016-385$ & 1991.3 & 111.9 & 5.3 & 1.8 & 3.6 & 1071.1 & 2.1 & 642.7 \\
\hline & LDGSW- & 2564.6 & 131.5 & 4.9 & 1.9 & 3.9 & 1168.5 & 2.3 & 701.1 \\
\hline & $2016-154 \mathrm{~A}$ & 1927.7 & 132.5 & 6.4 & 1.5 & 3.0 & 886.1 & 1.8 & 531.7 \\
\hline & & 1891.7 & 122.3 & 6.1 & 1.6 & 3.1 & 938.7 & 1.9 & 563.2 \\
\hline & LDGSW- & 1467.2 & 111.3 & 7.1 & 1.3 & 2.7 & 808.4 & 1.6 & 485.0 \\
\hline & 2015-143 & 1991.3 & 111.9 & 5.3 & 1.8 & 3.6 & 1071.1 & 2.1 & 642.7 \\
\hline & LDGSW- & 1663.9 & 103.7 & 5.9 & 1.6 & 3.2 & 971.6 & 1.9 & 583.0 \\
\hline & 2016-178A & 1548.0 & 139.3 & 8.3 & 1.2 & 2.3 & 690.3 & 1.4 & 414.2 \\
\hline & & 1772.7 & 119.8 & 6.3 & 1.5 & 3.0 & 900.6 & 1.8 & 540.4 \\
\hline & $\begin{array}{l}\text { LDGSW- } \\
\text { 2016-159B }\end{array}$ & 2098.6 & 118.5 & 5.3 & 1.8 & 3.6 & 1066.2 & 2.1 & 639.7 \\
\hline & Average & 1823.2 & 115.1 & $6.0 \pm$ & $1.6 \pm$ & $3.2 \pm$ & $965.5 \pm$ & $1.9 \pm 0$. & 579.3 \\
\hline & value & \pm 102.3 & \pm 4.9 & 0.3 & 0.1 & 0.1 & 44.5 & 1 & \pm 26.7 \\
\hline
\end{tabular}


327 Table 4 Stomatal data and carbon isotope data of Brachyphyllum and Cupressinocladus from

328 Laiyang Basin, and estimated $p \mathrm{CO}_{2}$ value based on the mechanistic model. $\mathrm{SN}=$ specimen number;

329 l_ad $=l \_$adaxial $(\mu \mathrm{m}) ; e l \_$ad $=e l \_$adaxial $(\mu \mathrm{m}) ; p \_$ad $=p \_$adaxial $(\mu \mathrm{m}) ; e p \_$ad $=e p \_$adaxial $(\mu \mathrm{m})$;

330 l_ab=l_abaxial $(\mu \mathrm{m}) ; e l \_\mathrm{ab}=e l \_a b a x i a l(\mu \mathrm{m}) ; p \_\mathrm{ab}=p \_$abaxial $(\mu \mathrm{m}) ; e p \_\mathrm{ab}=e p \_$abaxial $(\mu \mathrm{m})$;

$331 \delta=\delta^{13} C(\%) ; \delta_{a}=\delta^{13} C_{\text {air }}(\%) ; S D\left(\mathrm{~mm}^{-2}\right) ; a_{\max }\left(\mathrm{m}^{2}\right) ; \mathrm{G}=g_{c(\max )}\left(\mathrm{mol} \mathrm{m}^{-2} \mathrm{~s}^{-1}\right) ; \mathrm{G} 1 \mathrm{ab}=g_{c(o p) \_a b a x i a l}$ $332\left(\mathrm{~mol} \mathrm{~m}^{-2} \mathrm{~s}^{-1}\right) ; \mathrm{G} 2=g_{c(t o t)}\left(\mathrm{mol} \mathrm{m}^{-2} \mathrm{~s}^{-1}\right) ; \mathrm{C}=C_{i} / C_{a} ; A_{n}\left(\mu \mathrm{mol} \mathrm{m}^{-2} \mathrm{~s}^{-1}\right) ; \mathrm{P}=C a / p \mathrm{CO}_{2}(\mathrm{ppmv})$.

\begin{tabular}{|c|c|c|c|c|c|c|c|c|c|c|c|c|c|c|c|c|c|c|c|}
\hline Taxon & SN & $\begin{array}{l}l_{-} \\
\mathrm{ad}\end{array}$ & $\begin{array}{l}e l_{-} \\
\text {ad }\end{array}$ & $\begin{array}{l}p_{-} \\
\text {ad }\end{array}$ & $\begin{array}{c}e p \\
-^{\mathrm{a}} \\
\mathrm{d}^{2}\end{array}$ & $\begin{array}{l}l_{-} \\
\mathrm{ab}\end{array}$ & $\begin{array}{c}e l \\
-^{\mathrm{a}} \\
\mathrm{b}\end{array}$ & $\begin{array}{l}p_{-} \\
\mathrm{ab}\end{array}$ & $\begin{array}{c}e p \\
-^{\mathrm{a}} \\
\mathrm{b}\end{array}$ & $\delta$ & $\delta_{a}$ & $S D$ & $a_{\max }$ & G & $\begin{array}{l}\text { G1a } \\
\text { b }\end{array}$ & $\mathrm{G} 2$ & $\mathrm{C}$ & $A_{n}$ & $\mathrm{P}$ \\
\hline Cupre & LDGS & 13 & 1. & 19 & 3. & 13 & 0. & 24 & 6. & 26 & 7. & 86.6 & $1.37 \times$ & 0.30 & 0.06 & 0.06 & 0. & 10.6 & 441 \\
\hline ssinoc & W- & .0 & 6 & .6 & 8 & .7 & 8 & .4 & 2 & .9 & 5 & & $10^{-10}$ & 1 & 8 & 0 & 61 & 4 & \\
\hline ladus & $2016-$ & 11 & 1. & 19 & 3. & 15 & 0. & 21 & 7. & 26 & 7. & 86.4 & $2.38 \times$ & 0.40 & 0.07 & 0.05 & 0. & 10.7 & 463 \\
\hline \multirow[t]{27}{*}{ sp. } & $580 \mathrm{~A}$ & .4 & 0 & .1 & 3 & .7 & 8 & .9 & 2 & .9 & 5 & & $10^{-10}$ & 8 & 6 & 8 & 61 & 8 & \\
\hline & & 12 & 0. & 20 & 1. & 13 & 2. & 26 & 3. & 26 & 7. & 94.6 & $2.35 \times$ & 0.51 & 0.12 & 0.06 & 0. & 10.3 & 406 \\
\hline & & .0 & 4 & .5 & 4 & .9 & 2 & .2 & 3 & .9 & 5 & & $10^{-10}$ & 9 & 1 & 4 & 61 & 8 & \\
\hline & & 9. & 0. & 10 & 2. & 12 & 1. & 19 & 2. & 26 & 7. & 77.0 & $1.12 \times$ & 0.22 & 0.04 & 0.04 & 0. & 11.3 & 620 \\
\hline & & 7 & 1 & .7 & 8 & .4 & 1 & .1 & 0 & .9 & 5 & & $10^{-10}$ & 4 & 9 & 6 & 61 & 8 & \\
\hline & LDGS & 10 & 1. & 25 & 3. & 10 & 0. & 20 & 4. & 26 & 6. & 96.0 & $2.98 \times$ & 0.67 & 0.13 & 0.06 & 0. & 10.1 & 368 \\
\hline & W- & .1 & 6 & .2 & 5 & .2 & 9 & .5 & 0 & .3 & 9 & & $10^{-10}$ & 3 & 3 & 5 & 58 & 0 & \\
\hline & $2016-$ & 9. & 0. & 18 & 4. & 10 & 2. & 19 & 1. & 26 & 6. & 65.0 & $1.21 \times$ & 0.17 & 0.03 & 0.05 & 0. & 10.9 & 503 \\
\hline & $462 \mathrm{~A}$ & 4 & 8 & .3 & 7 & .2 & 6 & .1 & 6 & .3 & 9 & & $10^{-10}$ & 2 & 6 & 2 & 58 & 3 & \\
\hline & & 9. & 1. & 18 & 4. & 9. & 1. & 21 & 3. & 26 & 6. & 68.4 & $2.51 \times$ & 0.43 & 0.07 & 0.05 & 0. & 10.6 & 455 \\
\hline & & 5 & 3 & .7 & 1 & 1 & 2 & .4 & 7 & .3 & 9 & & $10^{-10}$ & 7 & 3 & 6 & 58 & 9 & \\
\hline & LDGS & 10 & 1. & 28 & 5. & 10 & 1. & 25 & 3. & 27 & 8. & 124. & $2.66 \times$ & 0.88 & 0.18 & 0.07 & 0. & 10.0 & 365 \\
\hline & W- & .5 & 1 & .1 & 8 & .1 & 3 & .8 & 4 & .5 & 0 & 3 & $10^{-10}$ & 8 & 5 & 4 & 63 & 5 & \\
\hline & $2016-$ & 10 & 0. & 29 & 2. & 10 & 1. & 24 & 3. & 27 & 8. & 126. & $1.34 \times$ & 0.52 & 0.11 & 0.07 & 0. & 10.0 & 361 \\
\hline & 1401 & .2 & 7 & .1 & 3 & .3 & 2 & .7 & 3 & .5 & 0 & 6 & $10^{-10}$ & 9 & 8 & 5 & 63 & 1 & \\
\hline & & 9. & 1. & 20 & 3. & 9. & 1. & 23 & 4. & 27 & 8. & 118. & $3.10 \times$ & 0.93 & 0.18 & 0.07 & 0. & 10.2 & 391 \\
\hline & & 7 & 5 & .8 & 4 & 0 & 4 & .7 & 4 & .5 & 0 & 6 & $10^{-10}$ & 1 & 8 & 0 & 63 & 6 & \\
\hline & & 8. & 0. & 21 & 1. & 10 & 0. & 25 & 4. & 27 & 8. & 110. & $1.71 \times$ & 0.51 & 0.11 & 0.07 & 0. & 10.2 & 390 \\
\hline & & 3 & 5 & .5 & 5 & .1 & 8 & .7 & 1 & .5 & 0 & 9 & $10^{-10}$ & 8 & 1 & 1 & 63 & 4 & \\
\hline & LDGS & 8. & 0. & 7. & 2. & 10 & 1. & 12 & 2. & 27 & 7. & 59.8 & $7.42 \times$ & 0.14 & 0.02 & 0.02 & 0. & 12.4 & 116 \\
\hline & W- & 7 & 8 & 7 & 6 & .4 & 8 & .1 & 8 & .1 & 7 & & $10^{-11}$ & 8 & 8 & 8 & 62 & 1 & 2 \\
\hline & $2015-$ & 8. & 1. & 10 & 3. & 7. & 1. & 13 & 3. & 27 & 7. & 76.4 & $1.61 \times$ & 0.08 & 0.01 & 0.04 & 0. & 11.5 & 684 \\
\hline & 907 & 2 & 5 & .7 & 4 & 4 & 9 & .4 & 6 & .1 & 7 & & $10^{-11}$ & 4 & 6 & 4 & 62 & 9 & \\
\hline & & 9. & 1. & 8. & 2. & 10 & 1. & 10 & 1. & 27 & 7. & 116. & $4.35 \times$ & 0.18 & 0.03 & 0.04 & 0. & 11.7 & 736 \\
\hline & & 1 & 6 & 8 & 4 & .1 & 5 & .0 & 6 & .1 & 7 & 6 & $10^{-11}$ & 5 & 7 & 1 & 62 & 4 & \\
\hline & Average & 10 & 1. & 18 & 3. & 10 & 1. & 20 & 3. & 27 & 7. & 93.4 & $1.72 \times$ & 0.43 & 0.08 & 0.05 & 0. & 10.8 & 525 \\
\hline & value & .0 & 0 & .5 & 2 & .9 & 4 & .6 & 7 & .0 & 6 & & $10^{-10}$ & 0 & 8 & 7 & 61 & 0 & \\
\hline Brach & LDGS & 9. & 0. & 15 & 2. & 10 & 1. & 22 & 6. & 23 & 4. & 112. & $4.36 \times$ & 0.14 & 0.03 & 0.06 & 0. & 10.3 & 402 \\
\hline yphyll & W- & 9 & 5 & .6 & 5 & .9 & 4 & .5 & 9 & .1 & 0 & 7 & $10^{-11}$ & 8 & 3 & 3 & 60 & 9 & \\
\hline um & $2016-$ & 10 & 0. & 15 & 0. & 7. & 0. & 12 & 4. & 23 & 4. & 105. & $1.16 \times$ & 0.43 & 0.08 & 0.05 & 0. & 10.9 & 501 \\
\hline obtusu & $162 \mathrm{~A}$ & .1 & 4 & .0 & 6 & 3 & 3 & .3 & 2 & .1 & 0 & 6 & $10^{-10}$ & 3 & 8 & 4 & 60 & 6 & \\
\hline $\mathrm{m}$ & LDGS & 9. & 0. & 14 & 0. & 8. & 1. & 14 & 7. & 23 & 4. & 79.2 & $7.79 \times$ & 0.21 & 0.03 & 0.05 & 0. & 11.3 & 591 \\
\hline
\end{tabular}


https://doi.org/10.5194/cp-2021-96

Preprint. Discussion started: 24 August 2021

(c) Author(s) 2021. CC BY 4.0 License.

\begin{tabular}{lllllllllllllllllll}
\hline W- & 7 & 6 & .7 & 5 & 7 & 6 & .9 & 1 & .9 & 8 & & $10^{-11}$ & 8 & 9 & 2 & 63 & 7 \\
2016- & 10 & 0. & 15 & 0. & 8. & 1. & 11 & 6. & 23 & 4. & 111. & $4.51 \times$ & 0.22 & 0.04 & 0.05 & 0. & 11.1 & 530 \\
385 & .2 & 2 & .4 & 6 & 3 & 1 & .7 & 6 & .9 & 8 & 9 & $10^{-11}$ & 2 & 8 & 6 & 63 & 6 & \\
LDGS & 5. & 0. & 9. & 2. & 7. & 1. & 15 & 5. & 22 & 3. & 131. & $2.77 \times$ & 0.17 & 0.03 & 0.06 & 0. & 10.4 & 417 \\
W- & 7 & 2 & 6 & 9 & 8 & 5 & .2 & 9 & .8 & 8 & 5 & $10^{-11}$ & 6 & 3 & 0 & 59 & 9 & \\
2016- & 8. & 0. & 19 & 5. & 7. & 1. & 9. & 3. & 22 & 3. & 132. & $7.09 \times$ & 0.36 & 0.06 & 0.06 & 0. & 10.4 & 403 \\
154A & 6 & 9 & .8 & 1 & 7 & 9 & 2 & 0 & .8 & 8 & 5 & $10^{-11}$ & 2 & 6 & 1 & 59 & 2 & \\
& 7. & 0. & 11 & 4. & 6. & 0. & 9. & 1. & 22 & 3. & 122. & $2.05 \times$ & 0.14 & 0.02 & 0.05 & 0. & 11.0 & 537 \\
& 8 & 8 & .2 & 5 & 5 & 8 & 9 & 2 & .8 & 8 & 3 & $10^{-11}$ & 2 & 8 & 0 & 59 & 7 & \\
LDGS & 8. & 0. & 18 & 3. & 9. & 0. & 21 & 6. & 23 & 4. & 118. & $1.38 \times$ & 0.48 & 0.09 & 0.06 & 0. & 10.3 & 395 \\
W- & 6 & 7 & .7 & 2 & 6 & 9 & .2 & 8 & .6 & 5 & 5 & $10^{-10}$ & 1 & 8 & 7 & 62 & 6 & \\
2016- & & & & & & & & & & & & & & & & & & \\
159B & & & & & & & & & & & & & & & & & \\
Average & 8. & 0. & 15 & 2. & 8. & 1. & 14 & 5. & 23 & 4. & 114. & $6.74 \times$ & 0.27 & 0.05 & 0.05 & 0. & 10.7 & 472 \\
value & 8 & 5 & .0 & 5 & 3 & 2 & .6 & 2 & .3 & 2 & 3 & $10^{-11}$ & 3 & 4 & 8 & 61 & 8 \\
\hline
\end{tabular}


https://doi.org/10.5194/cp-2021-96

Preprint. Discussion started: 24 August 2021

(c) Author(s) 2021. CC BY 4.0 License.

334 Table 5 The carbon isotope parameters of Brachyphyllum and Cupressinocladus from Laiyang

\begin{tabular}{llllll}
\hline \multicolumn{1}{c}{ Taxon } & Specimen number & $\delta^{13} \mathrm{C}(\%)$ & $\begin{array}{l}\delta^{13} \mathrm{C} \\
\mathrm{CO}(\%)\end{array}$ & $\Delta^{13} C_{\text {leaf }}$ & $p \mathrm{CO}_{2}(\mathrm{ppmv})$ \\
\hline Cupressinocladus & LDGSW-2016-580A & -26.90 & -5.78 & 21.70 & 401 \\
sp. & LDGSW-2016-462A & -26.30 & -5.78 & 21.07 & 353 \\
& LDGSW-2016-1401 & -27.50 & -5.78 & 22.33 & 460 \\
& LDGSW-2015-907 & -27.10 & -5.78 & 21.91 & 420 \\
& Average value & -26.95 & -5.78 & 21.76 & 409 \\
Brachyphyllum & LDGSw & -23.10 & -5.78 & 17.73 & 192 \\
& LDGSW-2016-162A & -23.90 & -5.78 & 18.56 & 222 \\
& LDGSW-2016-154A & -22.80 & -5.78 & 17.42 & 182 \\
& LDGSW-2016-159B & -23.60 & -5.78 & 18.25 & 210 \\
& Average value & -23.35 & -5.78 & 17.99 & 202 \\
\hline
\end{tabular}

335 Basin, and estimated $p \mathrm{CO}_{2}$ values based on the carbon isotope model.

336 
(A)

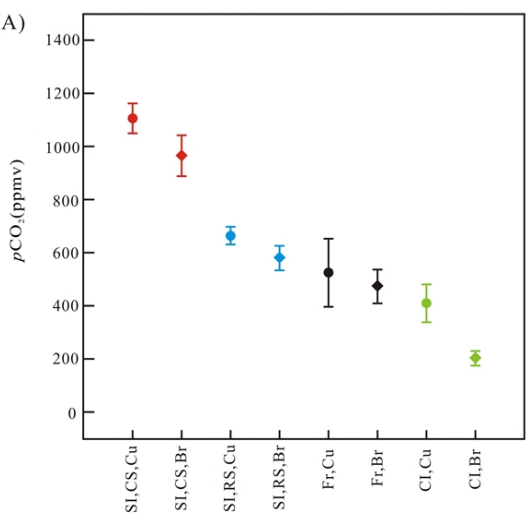

(B)

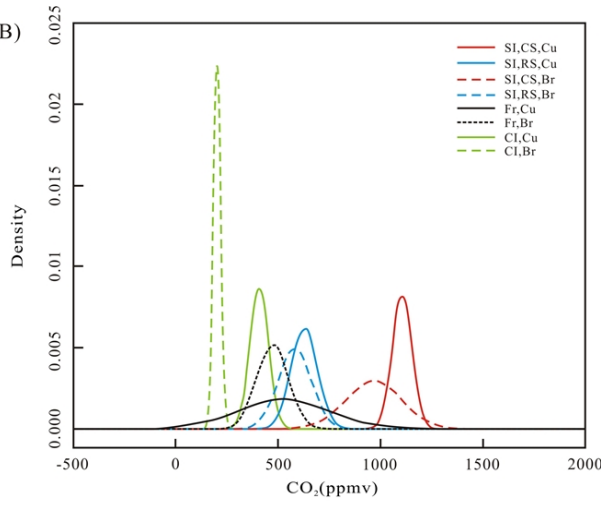

338 Fig. 5. A, The $p \mathrm{CO}_{2}$ ranges during the Early Cretaceous (Hauterivian-Barremian); The error bars indicate the $95 \%$ confidence interval for each $p \mathrm{CO}_{2}$ estimate; $\mathrm{B}$, Probability distributions from all proxy estimates; $\mathrm{SI}, \mathrm{CS}, \mathrm{Cu}=S R$-based method based on carboniferous standardization, Cupressinocladus sp.; SI, CS, Br=SR-based method based on carboniferous standardization, Brachyphyllum obtusum; $\mathrm{SI}, \mathrm{RS}, \mathrm{Cu}=S R$-based method based on recent standardization, Cupressinocladus sp.; SI, RS, $\mathrm{Br}=S R$-based method based on recent standardization, Brachyphyllum obtusum; $\mathrm{Fr}, \mathrm{Cu}=$ mechanistic model based on Cupressinocladus sp.; $\mathrm{Fr}, \mathrm{Br}=$ mechanistic model based on Brachyphyllum obtusum; $\mathrm{CI}, \mathrm{Cu}=$ carbon isotope model based on Cupressinocladus sp.; $\mathrm{CI}, \mathrm{Br}=$ carbon isotope model based on Brachyphyllum obtusum.

Based on the probability distributions from all proxy estimates, we note that most of the $95 \%$ confidence intervals of the recent standardization from SR-based method and mechanistic model overlap (Fig. 5B). However, the confidence interval of the carboniferous standardization from the $S R$-based method is much higher than the confidence interval of all other methods. The traditional method of using plant fossil SI to reconstruct $p \mathrm{CO}_{2}$ has the following disadvantages. First, the $S I$ has specific responses to $\mathrm{CO}_{2}$ concentration, so the quantitative estimation of $p \mathrm{CO}_{2}$ is limited to specific fossil species that are close to existing taxa (Küaschner et al., 2008). We must assume that these species have not suffered ecological and physiological evolution over time. However, this assumption has been questioned. Second, the response of the fitting function between $\mathrm{SI}$ and $p \mathrm{CO}_{2}$ is nonlinear, and the gradient decreases with increasing $\mathrm{CO}_{2}$ concentration. Therefore, it is difficult to calculate the accurate $p \mathrm{CO}_{2}$ value by the fitting function when the $\mathrm{CO}_{2}$ concentration in the environment is higher than the $\mathrm{CO}_{2}$ concentration of the current environment (Beerling and

Royer, 2002a; Beerling et al., 2009). Third, the traditional SR-based method depends mainly on the density of stomata and epidermal cells, without the change of stomatal length, while many experiments show that the change of stomatal length is often related to the atmospheric $\mathrm{CO}_{2}$ 
363 concentration (Konrad et al., 2008; Franks and Beerling, 2009). Finally, the statistical requirement 364 of $S I$ in this method is that epidermal cells should be clearly identified. However, due to the 365 influence of other epidermal structures (hair base, glands, etc.), it is difficult to obtain reliable 366 epidermal cell data for many plant fossils (Grein et al., 2013).

367 The error between the estimated value and the measured value of the mechanical model used 368 in this paper is $2.6 \%$, and its accuracy is significantly higher than the accuracy of other 369 reconstruction methods (Franks et al. 2014). In addition, the mechanical model avoids some of the abovementioned drawbacks of the traditional $S R$-based method for estimating the $p \mathrm{CO}_{2}$ and fully considers the influence of key parameters in gas exchange on the reconstruction results (such as the length and depth of the stomatal pores, the maximum opening area of the stoma, and the carbon isotope) (Franks et al. 2014). Therefore, this model has a strong reference when used to reconstruct the $\mathrm{pCO}_{2}$ in the geological period. We also see that the $95 \%$ confidence intervals of the $p \mathrm{CO}_{2}$ value estimated by two different plants of Cupressinocladus sp. and B. obtusum using the same method are highly coincident, increasing both accuracy and precision (Fig. 5B). We note that the $95 \%$ confidence interval of the $\mathrm{CCO}_{2}$ value obtained by Cupressinocladus sp. in the mechanical model is larger than the other $95 \%$ confidence interval, possibly due to the uncertainty of the value of $A_{n}$ (Fig. 5B). Therefore, when using the mechanical model to estimate the $p \mathrm{CO}_{2}$ value, selecting $A_{\mathrm{n}}$ values of species with similar habits is more appropriate (Reichgelt and D'Andrea, 2019).

We note that the $\mathrm{CO}_{2}$ estimate from the carbon isotope model is lower than the estimates from the $S R$-based method and mechanical model. The main reason is that the main parameter settings of the carbon isotope model are based on environmental factors since the Quaternary and plants' own factors (Schubert and Jahren, 2012, 2015). However, the main parameters of the Quaternary are still used in reconstructing the $\mathrm{COO}_{2}$ value of the Cretaceous, and whether this is

387 reasonable still requires much data to verify.

Finally, we note that during the Hauterivian-Barremian (the early period of the Early 389 Cretaceous), the $p \mathrm{CO}_{2}$ value was generally low, and it is feasible to use the mechanical model to 390 restore $p \mathrm{CO}_{2}$. In addition, the interval of the $p \mathrm{CO}_{2}$ value which is obtained by the mechanical 391 model is larger (443-693 ppm), and the $\mathrm{pCO}_{2}$ value shows greater instability, possibly because the 392 mechanical model is established based on living plants. Most of the biological anatomical parameters in the model, such as the thickness of the assimilation tissue and the conductivity of 394 the liquid part in the mesophyll, must be borrowed from the existing closest relatives of fossil 395 plants. Therefore, using this model will produce certain errors when recovering paleoclimate 396 parameters. According to the SR-based method, the $p \mathrm{CO}_{2}$ value estimated by Brachyphyllum 
397 obtusum (approximately 557-945 ppm) is lower than the $p \mathrm{CO}_{2}$ value estimated by 398 Cupressinocladus sp. (approximately 599-1252 ppm). This obvious difference may be due to the 399 different responses of different plants to $\mathrm{CO}_{2}$ concentrations.

4014.2 Comparison with other $p \mathrm{CO}_{2}$ records for the Early Cretaceous

402 The reconstruction methods of $\mathrm{pCO}_{2}$ during the Hauterivian-Barremian (Early Cretaceous) 403 include mainly calculations with plant fossil stomatal data (Haworth et al., 2005; Du et al., 2016; 404 Aucour et al., 2008; Sun et al., 2016; Passalia, 2009), isotope analysis (Heimhofer et al., 2004; 405 Wallmann, 2001; Ekart et al., 1999; Fletcher et al., 2005), biogeochemical models etc (Berner, 1994; Tajika, 1999; Berner and Kothavala, 2001; Rothman, 2002; Hansen and Wallman, 2003;

407 Bergman, 2004). The $p \mathrm{CO}_{2}$ value of the Hauterivian-Barremian obtained in this paper is generally 408 low, which is close to most of the $\mathrm{pCO}_{2}$ that was restored in the Early Cretaceous (Table 6; Fig. 6). 409 For example, the $p \mathrm{CO}_{2}$ values reconstructed by Haworth et al. (2005) based on the SR-based 410 method $\left(\mathrm{SI}_{(\mathrm{NLES})}=10.5\right.$, Pseudofrenelopsis parceramosa $)$ are approximately 653-1089 ppmv 411 (Early Hauterivian), 630-1050 ppmv (Late Hauterivian), 568-946 ppmv (Early Barremian) and 412 641-1068 ppmv (late Barremian). The Late Hauterivian $p \mathrm{CO}_{2}$ reconstructed by Dai and Sun (2018) 413 based on the SR-based method $\left(S I_{(\mathrm{NLES})}=5.8\right.$, Pseudofrenelopsis parceramosa $)$ is approximately 414 595-946 ppmv. Both of these results are highly coincident with the $p \mathrm{CO}_{2}$ value obtained by the 415 SR-based method in this paper. The $p \mathrm{CO}_{2}$ from the mechanical model in this paper is similar to 416 the late Barremian $p \mathrm{CO}_{2}$ (395-789 ppmv) obtained by Retallack (2009a) using Ginkgo fossils and 417 also similar to early Barremian $p \mathrm{CO}_{2}$ (560 ppmv) estimated by Robinson et al. (2002) using stable 418 isotopes of calcareous conglomerates from southern England. Huang et al. (2012) also believed 419 that $p \mathrm{CO}_{2}$ during Berriasian-Barremian was low based on the paleosol carbonate, and the late 420 Barremian $p \mathrm{CO}_{2}$ was about 365-644 ppmv. This value is also similar to the results recovered by 421 the recent standardization of the $S R$-based method and the mechanistic model in this paper. 
423 Table 6 Estimated $p \mathrm{CO}_{2}$ during the early stage of Early Cretaceous.

\begin{tabular}{|c|c|c|c|c|c|}
\hline Age & Proxy & $\begin{array}{l}S I \text { (fossil) } \\
(\%)\end{array}$ & $\begin{array}{l}p \mathrm{CO}_{2} \\
\text { (ppmv) }\end{array}$ & Locality & Data sources \\
\hline \multicolumn{6}{|l|}{ SR-based method } \\
\hline Berriasian & Ginkgo coriacea & $\begin{array}{l}3.79 \pm 0.22- \\
4.75 \pm 0.32\end{array}$ & $918-1920$ & $\begin{array}{l}\text { China, Inner } \\
\text { Mongolia, } \\
\text { Huolinghe }\end{array}$ & Sun et al., 2007 \\
\hline $\begin{array}{l}\text { Valanginian- } \\
\text { Hauterivian }\end{array}$ & Gingko coriacea & $3.4 \pm 0.1$ & 740 & $\begin{array}{l}\text { China, Inner } \\
\text { Mongolia, } \\
\text { Huolinghe }\end{array}$ & Chen et al., 2001 \\
\hline \multirow[t]{2}{*}{$\begin{array}{l}\text { Hauterivian- } \\
\text { Barremian }\end{array}$} & $\begin{array}{l}\text { Cupressinocladus } \\
\text { sp. }\end{array}$ & $5.3 \pm 0.2$ & $663-1105$ & $\begin{array}{l}\text { China, } \\
\text { Shandong }\end{array}$ & This study \\
\hline & $\begin{array}{l}\text { Brachyphyllum } \\
\text { obtusum }\end{array}$ & $6.0 \pm 0.3$ & $579-965$ & $\begin{array}{l}\text { China, } \\
\text { Shandong }\end{array}$ & This study \\
\hline Early Hauterivian & $\begin{array}{l}\text { Pseudofrenelopsis } \\
\text { parceramosa }\end{array}$ & $5.8 \pm 1.3$ & $653-1089$ & UK, USA & Haworth et al., 2005 \\
\hline \multirow[t]{2}{*}{ Late Hauterivian } & $\begin{array}{l}\text { Pseudofrenelopsis } \\
\text { parceramosa }\end{array}$ & $6.0 \pm 1.3$ & $630-1050$ & UK, USA & Haworth et al., 2005 \\
\hline & $\begin{array}{l}\text { Pseudofrenelopsis } \\
\text { papillosa }\end{array}$ & $5.8 \pm 0.5$ & $595-957$ & China, Fujian & Dai and Sun, 2018 \\
\hline Early Barremian & $\begin{array}{l}\text { Pseudofrenelopsis } \\
\text { parceramosa }\end{array}$ & $6.6 \pm 1.3$ & $568-946$ & UK, USA & Haworth et al., 2005 \\
\hline \multirow[t]{3}{*}{ Late Barremian } & $\begin{array}{l}\text { Pseudofrenelopsis } \\
\text { parceramosa }\end{array}$ & $5.9 \pm 1.0$ & $641-1068$ & UK, USA & Haworth et al., 2005 \\
\hline & Frenelopsis alata & $4.6 \pm 0.6$ & $700-1400$ & Argentina & $\begin{array}{l}\text { Aucour et al., 2008; } \\
\text { Passalia, } 2009\end{array}$ \\
\hline & Ginkgo & - & $395-789$ & USA & Retallack, 2009a,b \\
\hline $\begin{array}{l}\text { Barremian- } \\
\text { Aptian }\end{array}$ & Ginkgo & - & $400-3510$ & USA & Retallack, 2009a,b \\
\hline \multicolumn{6}{|l|}{ Mechanistic model } \\
\hline $\begin{array}{l}\text { Berriasian-- } \\
\text { Valanginian }\end{array}$ & $\begin{array}{l}\text { Otozamites } \\
\text { ornatus }\end{array}$ & - & 416 & $\begin{array}{l}\text { Patagonia, } \\
\text { Argentina }\end{array}$ & $\begin{array}{l}\text { De Seoane, } 2001 ; \\
\text { Franks et al., } 2014\end{array}$ \\
\hline $\begin{array}{l}\text { Hauterivian- } \\
\text { Barremian }\end{array}$ & $\begin{array}{l}\text { Cupressinocladus } \\
\text { sp. }\end{array}$ & - & $432-691$ & $\begin{array}{l}\text { China, } \\
\text { Shandong }\end{array}$ & This study \\
\hline & $\begin{array}{l}\text { Brachyphyllum } \\
\text { obtusum }\end{array}$ & - & $371-817$ & $\begin{array}{l}\text { China, } \\
\text { Shandong }\end{array}$ & This study \\
\hline \multicolumn{6}{|c|}{ Other carbon isotope analysis } \\
\hline $\begin{array}{l}\text { Early-middle } \\
\text { Berriasian }\end{array}$ & $\begin{array}{l}\text { Paleosol } \\
\text { carbonates }\end{array}$ & - & $287-389$ & China & Huang et al., 2012 \\
\hline $\begin{array}{l}\text { Early } \\
\text { Valanginian }\end{array}$ & $\begin{array}{l}\text { Paleosol } \\
\text { carbonates }\end{array}$ & - & $237-245$ & China & Huang et al., 2012 \\
\hline $\begin{array}{l}\text { Hauterivian- } \\
\text { Barremian }\end{array}$ & $\begin{array}{l}\text { Carbon isotope of } \\
\text { Brachyphyllum }\end{array}$ & - & 409 & $\begin{array}{l}\text { China, } \\
\text { Shandong }\end{array}$ & This study \\
\hline & Carbon isotope of & - & 202 & China, & This study \\
\hline
\end{tabular}


https://doi.org/10.5194/cp-2021-96

Preprint. Discussion started: 24 August 2021

(c) Author(s) 2021. CC BY 4.0 License.

\begin{tabular}{c} 
Climate \\
of the Past \\
\hline Discussions
\end{tabular}

\begin{tabular}{|c|c|c|c|c|c|}
\hline & Cupressinocladus & & & Shandong & \\
\hline $\begin{array}{l}\text { Hauterivian/Apti } \\
\text { an-Albian }\end{array}$ & $\begin{array}{l}\text { Paleosol } \\
\text { carbonates }\end{array}$ & - & 2300 & Japan, Korea & Lee et al., 1999 \\
\hline Early Barremian & Calcrete nodules & - & 560 & UK & $\begin{array}{l}\text { Robinson et al., } \\
2002\end{array}$ \\
\hline Late Barremian & $\begin{array}{l}\text { Paleosol } \\
\text { carbonates }\end{array}$ & - & $365-644$ & China & Huang et al., 2012 \\
\hline
\end{tabular}

424 

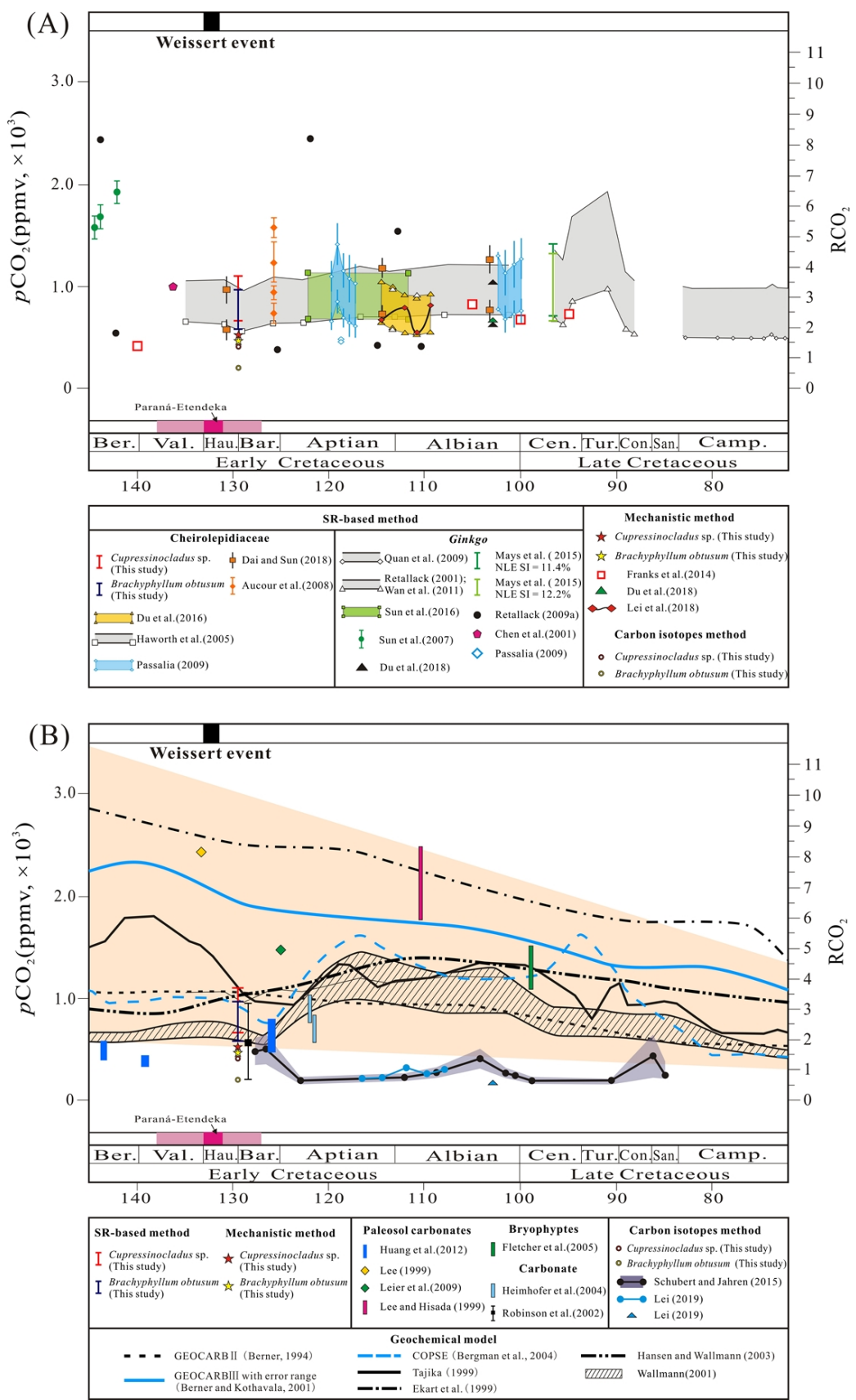

426 Fig. 6. A: Our estimated $p \mathrm{CO}_{2}$ values during Hauterivian-Barremian (Early Cretaceous), and

427 previous data based on $S R$-based method and mechanistic model; B: Our estimated $p \mathrm{CO}_{2}$ values 428 during Hauterivian-Barremian, and previous data based on biogeochemical models and carbon 429 isotopes. 

(2001) and the geochemical model COPSE established by Bergman et al. (2004) both show that $p \mathrm{CO}_{2}$ during the Hauterivian-Barremian was relatively low compared with other $p \mathrm{CO}_{2}$ values of the Early Cretaceous. The $p \mathrm{CO}_{2}$ obtained by the recent standardization of the $S R$-based method and the mechanistic model in this paper are close to the value of the Hauterivian-Barremian recovered by Hansen and Wallmann (2003). However, the $p \mathrm{CO}_{2}$ value estimated by the carboniferous standardization of the $S R$-based method is slightly higher, which is closer to the concentration curves obtained from the geochemical models GEOCARB II, COPSE and Tajika (1999) (Fig. 6).

Schubert and Jahren (2015) reconstructed $p \mathrm{CO}_{2}$ and its changes during the past 30,000 years 441 based on the carbon isotope model with a large amount of global terrestrial organic matter and carbon isotopic composition of plant fossils. The reconstruction results are consistent with the results known from ice cores (Schubert and Jahren, 2015). The $p \mathrm{CO}_{2}$ during the BarremianSantonian Cretaceous reconstructed by Barral et al. (2017a) with the plant carbon isotope model is about 185-502 ppmv, which is generally lower than the results from plant stomatal method, isotope method, biogeochemical model, etc (Fig. 6). Furthermore, the $p \mathrm{CO}_{2}$ value reconstructed in this paper based on the carbon isotope method during the Hauterivian-Barremian is also lower than the results of the $S R$-based method and the mechanistic model and close to the results of Barral et al (2017a) (Fig. 6). Therefore, in combination with previous studies, the $p \mathrm{CO}_{2}$ values reconstructed from the carbon isotope model are generally lower than the $p \mathrm{CO}_{2}$ values

451 reconstructed from other methods.

453 4.3. The $p \mathrm{CO}_{2}$ records and Weissert event carbon-isotope excursion (CIE), the Weissert event, which is regarded as a global perturbation of coupled oceanic and atmospheric carbon reservoirs based on the wide documentation from marine bulkrock and belemnite carbonates and fossil wood organic matter (Lini et al., 1992; Wortmann and Weissert, 2000; Weissert and Erba, 2004; Gröcke et al., 2005; Price et al., 2018; Jelby et al., 459 2020). The latest estimate of the timing of the onset of the Weissert event is ascertained to be $460135.22 \pm 1 \mathrm{Ma}$ derived from U-Pb ages from tuff layers in the Neuquén Basin and an update of the 461 Valanginian-Hauterivian astrochronological time scale (Aguirre-Urreta et al., 2015; Martinez et al., 2015). Most studies have confirmed that the Valanginian Weissert event coincided with the

463 onset of the eruptive phase of the Paraná-Etendeka, which has recently been dated between 
134.6 \pm 0.6 Ma and 134.3 \pm 0.8 Ma (Price et al., 2018).

The intense volcanism in the geological age affected seawater chemistry in different ways. The widely dispersed volcanic emissions formed by Paraná-Etendeka volcanic activity possibly caused increased concentrations of toxic trace metals in the surface ocean, affecting marine primary producers (Möller et al. , 2020). Following the positive carbon isotope excursion of the Weissert event, fertilization of the oceans increased, which caused sequestration of marine organic carbon (Erba et al., 2004; Duchamp-Alphonse et al., 2007). Then the weathering of basalt gradually strengthened, which eventually led to a decrease in the $p \mathrm{CO}_{2}$ and global temperature in the last stages of the Weissert event (the late Valanginian) (Möller et al., 2020). This cooling event has been inferred based on glendonite occurrences from the Canadian Arctic Archipelago, ice rafted debris in central Australia, belemnites and fish tooth enamel $\delta^{18} \mathrm{O}$ data from northern Germany, Western Siberia, northern Italy, France and Spain (Kemper and Schmitz, 1981; Frakes and Francis, 1988; Podlaha et al., 1998; Price and Mutterlose, 2004; Weissert and Erba, 2004; McArthur et al., 2007; Bodin et al., 2015; Meissner et al., 2015; Price et al., 2018; Möller et al. , 2020).

Most of the $\mathrm{pCO}_{2}$ values that have been recovered thus far all reflect the significant decrease during the Hauterivian-Barremian, such as the $p \mathrm{CO}_{2}$ values obtained from $S R$-based method of Pseudofrenelopsis parceramosa, the geochemical model COPSE, and the global carbon cycle model established by Tajika (1999) and Wallmann (2001), all of the Hauterivian-Barremian $p \mathrm{CO}_{2}$ values obtained from these studies reached the lowest point in Early Cretaceous (Tajika, 1999; Wallmann, 2001; Bergman et al., 2004; Haworth et al., 2005). Similarly, the HauterivianBarremian $p \mathrm{CO}_{2}$ values in Laiyang Basin reconstructed by both fossil coniferous species $(C$. sp. and $B$. obtusum) from each method are relatively low compared with other $p \mathrm{CO}_{2}$ values in the Early Cretaceous. All of these $\mathrm{pCO}_{2}$ records also reflect the cooling event in the final stage of the Weissert event.

\section{Conclusions}

In this study, we present a new $p \mathrm{CO}_{2}$ record for the Hauterivian-Barremian on the basis of fossil leaves (Cupressinocladus sp. and Brachyphyllum obtusum) collected from Laiyang Basin.

All the required fossil cuticle and isotopic parameters were measured and three different proxy methods were applied to estimate $p \mathrm{CO}_{2}$. The $p \mathrm{CO}_{2}$ values estimated using the SR-based method were approximately 579-663 ppmv calibrated with recent standardization and 966-1106 ppmv calibrated with carboniferous standardization. The $p \mathrm{CO}_{2}$ value estimated using the mechanistic model was about 472-525 ppmv. The $p \mathrm{CO}_{2}$ value estimated using the carbon isotope model was approximately 472-525 ppmv. By summarizing the $p \mathrm{CO}_{2}$ record estimated using $S R$-based, 


\section{Competing interests}

\section{Acknowledgments}

\section{Financial support} 203103).

\section{References}

We declare that we have no financial and personal relationships with other people or organizations that can inappropriately influence our work.

We are very grateful to the editor and anonymous reviewers for useful comments that significantly improved the manuscript.

This study was supported by the Second Tibetan Plateau Scientific Expedition and Research Program (STEP) (Grant No. 2019QZKK0704), the National Natural Science Foundation of China (No. 41902017), the Natural Science Foundation of Gansu Province (No. 2021000050), the Key Laboratory Project of Gansu Province (No. SZDKFJJ20201208), and State Key Laboratory of Palaeobiology and Stratigraphy (Nanjing Institute of Geology and Palaeontology, CAS) (No.

Aguirre-Urreta, B., Lescano, M., Schmitz, M.D., Tunik, M., Concheyro, A., Rawson, P.F., Ramos, V.A.: Filling the gap: new precise Early Cretaceous radioisotopic ages from the Andes, Geol. Mag., 152, 557-564, https://doi.org/10.1017/S001675681400082X, 2015. Arens, N.C., Jahrens, A.H., Amundson, R.: Can $\mathrm{C}_{3}$ plants faithfully record the carbon isotopic 
composition of atmospheric carbon dioxide? Palaeobiology, 26, 137-164, https://doi.org/10.1666/0094-8373(2000)026<0137:CCPFRT>2.0.CO;2, 2000.

Aucour, A.M., Gomez, B., Sheppard, S.M.F., Thevenard, F.: $\delta^{13} \mathrm{C}$ and stomatal number variability in the Cretaceous conifer Frenelopsis, Palaeogeography, Palaeoclimatology, Palaeoecology, 257, 462-473, https://doi.org/10.1016/j.palaeo.2007.10.027, 2008.

Barclay, R.S., Mcelwain, J.C., Sageman, B.B.: Carbon sequestration activated by a volcanic $\mathrm{CO}_{2}$ pulse during Ocean Anoxic Event 2, Nature Geoscience, 3, 205-208, doi:10.1038/ngeo757, 2010.

Barral, A., Gomez, B., Fourel, F., Daviero-Gomez, V., Lécuyer, C.: $\mathrm{CO}_{2}$ and temperature decoupling at the million-year scale during the Cretaceous Greenhouse, Scientific Reports, 7, 8310, DOI:10.1038/s41598-017-08234-0, 2017a.

Barral, A., Gomez, B., Legendre, S., Lécuyer, C.: Evolution of the carbon isotope composition of atmospheric $\mathrm{CO}_{2}$ throughout the Cretaceous, Palaeogeography, Palaeoclimatology, Palaeoecology, 471, 40-47, https://doi.org/10.1016/j.palaeo.2017.01.034, 2017b.

Beerling, D.J., Fox, A., Anderson, C.W.: Quantitative uncertainty analyses of ancient atmospheric $\mathrm{CO}_{2}$ estimates from fossil leaves, American Journal of Science, 309, 775-787, https://doi.org/10.2475/09.2009.01, 2009.

Beerling, D.J., Osborne, C., Chaloner, W.: Evolution of leaf-form in land plants linked to atmospheric $\mathrm{CO}_{2}$ decline in the Late Palaeozoic era, Nature, 410, 352-354, https://doi.org/10.1038/35066546, 2001.

Beerling, D.J., Royer, D.L.: Fossil plants as indicators of the Phanerozoic global carbon cycle, Annual Review of Earth and Planetary Sciences, 30, 527-556, https://doi.org/10.1146/annurev.earth.30.091201.141413, 2002a.

Beerling, D.J., Royer, D.L.: Reading a $\mathrm{CO}_{2}$ signal from fossil stomata, New Phytologist, 153, 387-397, https://doi.org/10.1046/j.0028-646X.2001.00335.x, 2002b.

Bergman, N.M., Lenton, T.M., Watson, A.J.: COPSE: a new model of biogeochemical cycling over Phanerozoic time, American Journal of Science, 304, 397-437, 2004.

Berner, R.A.: GEOCARB II: a revised model of atmospheric $\mathrm{CO}_{2}$ over Phanerozoictime, Am. J. Sci., 294, 56-91, https://doi.org/10.2475/ajs.304.5.397, 1994.

Berner, R.A., Kothavala, Z.: GEOCARB III: revised model of atmospheric $\mathrm{CO}_{2}$ over Phanerozoic time, Am. J. Sci., 301, 182-204, https://doi.org/10.2475/ajs.301.2.182, 2001.

Bodin, S., Meissner, P., Janssen, N.M.M., Steuber, T., Mutterlose, J.: Large igneous provinces and organic carbon burial: Controls on global temperature and continental weathering during the Early Cretaceous, Glob. Planet. Chang., 133, 238-253, https://doi.org/10.1016/j.gloplacha.2015.09.001, 2015

Boucot, A.J., Gray, J.: A critique of Phanerozoic climatic models involving changes in the $\mathrm{CO}_{2}$ content of the atmosphere, Earth Sci. Rev., 56 (1-4), 1-159, https://doi.org/10.1016/S0012-8252(01)00066-6, 2001.

Chen, L.Q., Li, C.S., Chaloner, W.G., Beerling, D.J., Sun, Q.G., Collinson, M.E., Mitchell, P.L.: Assessing the potentialfor the stomatal characters of extant and fossil Ginkgo leaves tosignal atmospheric $\mathrm{CO}_{2}$ change, American Journal of Botany, 88, 1309-1315, https://doi.org/10.2307/3558342, 2001.

Chen, P.J., Cao, M.Z., Pan, H.Z., Ye, C.H., Li, W.B., Shen, Y.B., Chen, J.H.: Issues of continental strata in Mesozoic from Shandong, Journal of Stratigraphy, 4 (4), 301-309, 1980. 
Dai, J., Sun, B.N.: Early Cretaceous atmospheric $\mathrm{CO}_{2}$ estimates based on stomatal index of Pseudofrenelopsis papillosa (Cheirolepidiaceae) from southeast China, Cretaceous Research, 85, 232-242, https://doi.org/10.1016/j.cretres.2017.08.011, 2018.

De Seoane, L.V.: Cuticular study of Bennettitales from the Springhill Formation, Lower Cretaceous of Patagonia, Argentina, Cretaceous Research, 22, 461-479, https://doi.org/10.1006/cres.2001.0266, 2001.

Du, B.X., Lei, X.T., Zhang, M.Z., Wang, S., Li, A.J., Du, Z., Xing, W.W.: Late early Cretaceous climate and $p \mathrm{CO}_{2}$ estimates in the Liupanshan Basin, northwest China, Palaeogeography, Palaeoclimatology, Palaeoecology, 503, 26-39, https://doi.org/10.1016/j.palaeo.2018.04.023, 2018.

Du, B.X., Sun, B.N., Zhang, M.Z., Yang, G.L., Xing, L.T., Tang, F.J., Bai, Y.X.: Atmospheric palaeo- $\mathrm{CO}_{2}$ estimates based on the carbon isotope and stomatal data of Cheirolepidiaceae from the Lower Cretaceous of the Jiuquan Basin, Gansu Province, Cretaceous Research, 62, 142-153, https://doi.org/10.1016/j.cretres.2015.07.020, 2016.

Duchamp-Alphonse, S., Fiet, N., Adatte, T., Pagel, M.: Climate and sea-level variations along the northwestern Tethyan margin during the Valanginian $\mathrm{C}$-isotope excursion: Mineralogical evidence from the Vocontian Basin (SE France), Palaeogeography, Palaeoclimatology, Palaeoecology, 302, 243-254, https://doi.org/10.1016/j.palaeo.2011.01.015, 2011.

Ekart, D.D., Cerling, T.E., Montanez, I.P., Tabor, N.J.: A 400 million year carbon isotope record of pedogenic carbonate: implications for paleoatmospheric carbon dioxide, American Journal of Science, 299, 805-827, http://earth.geology.yale.edu/ ajs/1999/10.1999.01Ekart, 1999.

Erba E., Bartolini A., Larson R.L.: Valanginian Weissert oceanic anoxic event, Geology, 32, 149152, https://doi.org/10.1130/G20008.1, 2004.

Farquhar, G.D., And, J.R.E., Hubick, K.T.: Carbon Isotope Discrimination and Photosynthesis, Annu. Rev. Plant Physiol. Plant Mol. Biol., 40, 503-537, https://doi.org/10.1146/annurev.pp.40.060189.002443, 1989.

Farquhar, G.D., Caemmerer, S.V., Berry, J.A.: A biochemical model of photosynthetic $\mathrm{CO}_{2}$ assimilation in leaves of $\mathrm{C}_{3}$ species, Planta, 149, 78-90, doi: 00320935/80/0149/0078/\$02.60, 1980.

Farquhar, G.D., O'leary, M.H., Berry, J.A.: On the Relationship Between Carbon Isotope Discrimination and the Intercellular Carbon Dioxide Concentration in Leaves, Functional Plant Biology, 9, 281-292, https://doi.org/10.1071/PP9820121, 1982.

Fletcher, B.J., Beerling, D.J., Brentnall, S.J., Royer, D.L.: Fossil bryophytes as recorders of ancient $\mathrm{CO}_{2}$ levels: experimental evidence and a Cretaceous case study, Glob. Biogeochem. Cycles, 19, 1-13, https://doi.org/10.1029/2005GB002495, 2005.

Fletcher, B.J., Brentnall, S.J., Anderson, C.W., Berner, R.A., Beerling, D.J.: Atmospheric carbon dioxide linked with Mesozoic and early Cenozoic climate change, Nature Geoscience, 1, 43-48, doi:10.1038/ngeo.2007.29, 2008.

Florin, R.: On Jurassic taxads and conifers from north-western Europe and eastern Greenland, Acta Horti Bergiani, 17, 257-402, 1958.

Florin, R.: The distribution of conifer and taxad genera in time and space, Acta Horti Bergiani, 20(4), 121-312, 1963. 
Föllmi, K.B.: Early Cretaceous life, climate and anoxia, Cretaceous Research, 35, 230-257, https://doi.org/10.1016/j.cretres.2011.12.005, 2012.

Frakes, L.A., Francis, J.E.: A guide to Phanerozoic cold polar climates from highlatitude icerafting in the Cretaceous, Nature, 333, 547-549, https://doi.org/10.1038/333547a0, 1988.

Franks, P.J., Adams, M.A., Amthor, J.S., Barbour, M.M., Berry, J.A., Ellsworth, D.S., Farquhar, G.D., Ghannoum, O., Loyd, J.L., McDowell, N., Norby, R.J., Tissue, D.T., Caemmerer, S.: Sensitivity of plants to changing atmospheric $\mathrm{CO}_{2}$ concentration: from the geological past to the next century, New Phytol, 197, 1077-1094, https://doi.org/10.1111/nph.12104, 2013.

Franks, P.J., Drake, P.L., Beerling, D.J.: Plasticity in maximum stomatal conductance constrained by negative correlation between stomatal size and density: an analysis using Eucalyptus globules, Plant Cell Environ., 32, 1737-1748, https://doi.org/10.1111/j.13653040.2009.002031.x, 2009.

Franks, P.J., Royer, D.L., Beerling, D.J., Van de Water, P.K., Cantrill, D.J., Barbour, M.M., Berry, J.A.: New constraints on atmospheric $\mathrm{CO}_{2}$ concentration for the Phanerozoic, Geophysical Research Letters, 41, 4685-4694, https://doi.org/10.1002/2014GL060457, 2014.

Gomez, B., Ewin, T. A., Daviero-Gomez, V.: The conifer Glenrosa falcata sp. nov. from the Lower Cretaceous of Spain and its palaeoecology, Review of Palaeobotany and Palynology, 172, 21-32, https://doi.org/10.1016/j.revpalbo.2012.01.009, 2012.

Grein, M., Oehm, C., Konrad, W., Utescher, T., Kunzmann, L., Roth-Nebelsick, A.: Atmospheric $\mathrm{CO}_{2}$ from the late Oligocene to early Miocene based on photosynthesis data and fossil leaf characteristics, Palaeogeography, Palaeoclimatology, Palaeoecology, 374, 41-51, https://doi.org/10.1016/j.palaeo.2012.12.025, 2013.

Grimaldi, D., Engel, M.S. (Eds.): Evolution of the Insects, Cambridge University Press, New York, pp. 772, 2005.

Gröcke, D.R., Price, G.D., Robinson, S.A., Baraboshkin, E.Y., Mutterlose, J., Ruffell, A.H.: The Upper Valanginian (Early Cretaceous) positive carbon-isotope event recorded in terrestrial plants, Earth Planet. Sci. Lett., 240, 495-509, https://doi.org/10.1016/j.epsl.2005.09.001, 2005.

Hansen, K.W., Wallmann, K.: Cretaceous and Cenozoic evolution of seawater composition, atmospheric $\mathrm{O}_{2}$ and $\mathrm{CO}_{2}$, American Journal of Science, 303, https://doi.org/10.2475/ajs.303.2.94, 2003.

Harris, T.M.: Naming a fossil conifer, J. Sen. Memorial, 243-252, 1969.

Haworth ,M., Heath, J., Mcelwain, J.C.: Differences in the response sensitivity of stomatal index to atmospheric $\mathrm{CO}_{2}$ among four genera of Cupressaceae conifers, Annals of Botany, 105, 411-418, https://doi.org/10.1093/aob/mcp309, 2010.

Haworth, M., Hesselbo, S.P., Mcelwain, J.C., Robinson, S.A., Brunt, J.W.: Mid-Cretaceous $p \mathrm{CO}_{2}$ based on stomata of the extinct conifer Pseudofrenelopsis (Cheirolepidiaceae), Geology, 33, 749-752, https://doi.org/10.1130/G21736.1, 2005.

Heimhofer, U., Hochulib, P.A., Herrlec, J.O., Andersend, N., Weisserta, H.: Absence of major vegetation and palaeoatmospheric $p \mathrm{CO}_{2}$ changes associated with oceanic anoxic event 1a (Early Aptian, SE France), Earth Planet. Sci. Lett., 223, 303-318, 
https://doi.org/10.1016/j.epsl.2004.04.037, 2004.

Huang, C.M., Retallack, G.J., Wang, C.S.: Early Cretaceous atmospheric $p \mathrm{CO}_{2}$ levels recorded from pedogenic carbonates in China, Cretaceous Research, 33, 42-49, https://doi.org/10.1016/j.cretres.2011.08.001, 2012.

Huo, T.F., Yang D.B., Xu, W.L., Wang F., Liu H.B., Shi J.P.: U-Pb Ages and Hf Isotope Compositions of Detrital Zircons from the Sandstone in the Early Cretaceous Wawukuang Formation in the Jiaolai Basin, Shandong Province and its Tectonic Implications, Geotectonica et Metallogenia, 39(2), 355-368, 2015.

Jelby, M.E., Śliwińska, K.K., Koevoets, M.J., Alsen, P., Vickers, M.L., Olaussen, S., Stemmerik, L.: Arctic reappraisal of global carbon-cycle dynamics across the Jurassic-Cretaceous boundary and Valanginian Weissert Event, Palaeogeography, Palaeoclimatology, Palaeoecology, 555, 109847, https://doi.org/10.1016/j.palaeo.2020.109847, 2020.

Jenkyns, H.C.: Geochemistry of Oceanic Anoxic Events, Geochemistry, Geophysics, Geosystems, 11(3), Q03004, doi:10.1029/2009GC002788, 2010.

Jin, P.H., Dong, J.L., Wang, Z.X., Yuan, X.C., Hua, Y.F., Du, B.X., Sun, B.N.: A new species of Elatides from the Lower Cretaceous in Shandong province, Eastern China and its geographic significance, Cretaceous Research, 85, 109-127, https://doi.org/10.1016/j.cretres.2017.11.022, 2018.

Jin, P.H., Mao, T., Dong, J.L., Wang, Z.X., Xu, X,H., Du, B.X., Sun, B.N.: A new species of Cupressinocladus from the Lower Cretaceous of Guyang Basin, Inner Mongolia, North China and its microstructure, Acta Geological Sinica (English Edition), 4, 1200-1214, https://doi.org/10.1111/1755-6724.13355, 2017.

Kemper, E., Schmitz, H.H.: Glendonite-Indikatoren des polarmarinen Ablagerungsmilieus, Geol. Rundsch., 2, 759-773, 1981.

Konrad, W., Katul, G., Roth-Nebelsick, A., Grein, M.: A reduced order model to analytically infer atmospheric $\mathrm{CO}_{2}$ concentration from stomatal and climate data, Advances in Water Resources, 104, 145-157, https://doi.org/10.1016/j.advwatres.2017.03.018, 2017.

Konrad, W., Roth-Nebelsick, A., Grein, M.: Modelling of stomatal density response to atmospheric $\mathrm{CO}_{2}$, Journal of Theoretical Biology, 253(4), 638-658, https://doi.org/10.1016/j.jtbi.2008.03.032, 2008.

Kürschner, W.M., Kvaček, Z., Dilcher, D.L.: The impact of Miocene atmospheric carbon dioxide fluctuations on climate and the evolution of terrestrial ecosystems, Proceedings of the National Academy of Sciences, 105, 449-453, https://doi.org/10.1073/pnas.0708588105, 2008.

Lee, Y.I.: Stable isotopic composition of calcic paleosol of the Early Cretaceous Hasandong Formation, southeastern Korea, Palaeogeography, Palaeoclimatology, Palaeoecology, 150 (1-2), 123-133, https://doi.org/10.1016/S0031-0182(99)00010-3, 1999.

Lee, Y.I., Hisada, K.I.: Stable isotopic composition of pedogenic carbonates of the Early Cretaceous Shimonoseki Subgroup, western Honshu, Japan, Palaeogeography, Palaeoclimatology, Palaeoecology, 153 (1-4), 127-138, https://doi.org/10.1016/S00310182(99)00069-3, 1999.

Lei, X.T.: Early Cretaceous Cheirolepidiaceae from the Jiuquan and Liupanshan Basins and $p \mathrm{CO}_{2}$ estimates, Ph.D. thesis, Lanzhou University, China, 27-40pp., 2019 (in Chinese with English abstract). 
Lei, X.T., Du, Z., Du, B.X., Zhang, M.Z., Sun, B.N.: Middle Cretaceous $p \mathrm{CO}_{2}$ variation in Yumen, Gansu Province and its response to the climate events, Acta Geologica Sinica-English Edition, 92(2), 801-813, https://doi.org/10.1111/1755-6724.13555, 2018.

Leier, Heimhofer A., Quade, J., DeCelles, P., Kapp, P.: Stable isotopic results from paleosol carbonate in South Asia: paleoenvironmental reconstructions and selective alteration, Earth Planet. Sci. Lett., 279, 242-254, https://doi.org/10.1016/j.eps1.2008.12.044, 2009.

Li, H., Yu, J.X., McElwain, J.C., Yiotis, C., Chen, Z.Q.: Reconstruction of atmospheric $\mathrm{CO}_{2}$ concentration during the late Changhsingian based on fossil conifers from the Dalong Formation in South China, Palaeogeography, Palaeoclimatology, Palaeoecology, 519, 37 48, https://doi.org/10.1016/j.palaeo.2018.09.006, 2019.

Li, R.H., Zhang, G.W.: New Dinosaur Ichotaxon from the Early Cretaceous Laiyang Group in the Laiyang Basin, Shandong Province, Geological review, 46(6), 605-610, 2000 (in Chinese with English abstract).

Lin, Q.: On Penaphis Lin, 1980 of Cretaceous (Callaphididae, Homoptera) and its coevolutionary relationships, Acta Palaeontologica Sinica, 34, 194-204, 1995 (in Chinese with English abstract).

Ling, W.L., Xie, X.J., Liu, X.M., Cheng, J.P.: Zircon U-Pb dating on the Mesozoic volcanic suite from the Qingshan Group stratotype section in eastern Shandong Province and its tectonic significance, Science in China, 50(6), 813-824, 2007.

Lini, A., Weissert, H., Erba, E.: The Valanginian carbon isotope event: a first episode of greenhouse climate conditions during the Cretaceous, Terra Nova, 4, 374-384, https://doi.org/10.1111/j.1365-3121.1992.tb00826.x, 1992.

Luo, S.L., Liu, M.W., Sha, Y.X., Wang, B., Hong, Y.C., Wang, W.L., Yu, J.X. (Eds.): The stratigraphy and palaeontology of Laiyang Basin, Shandong province, Geological Publishing House, Beijing pp. 24-159, 1990.

Martinez, M., Deconinck, J.F., Pellenard, P., Riquier, L., Company, M., Reboulet, S., Moiroud, M.: Astrochronology of the Valanginian-Hauterivian stages (Early Cretaceous): Chronological relationships between the Paraná-Etendeka large igneous province and the Weissert and the Faraoni events, Global and Planetary Change, 131, 158-173, https://doi.org/10.1016/j.gloplacha.2015.06.001, 2015.

McArthur, J.M., Janssen, N.M.M., Reboulet, S., Leng, M.J., Thirlwall, M.F., van de Schootbrugge, B.: Palaeotemperatures, polar ice-volume, and isotope stratigraphy $\left(\mathrm{Mg} / \mathrm{Ca}, \delta^{18} \mathrm{O}, \delta^{13} \mathrm{C}\right.$, ${ }^{87} \mathrm{Sr} /{ }^{86} \mathrm{Sr}$ ): the Early Cretaceous (Berriasian, Valanginian, Hauterivian), Palaeogeography, Palaeoclimatology, Palaeoecology, 248, 391-430, https://doi.org/10.1016/j.palaeo.2006.12.015, 2007.

Mcelwain, J.C.: Do fossil plants signal palaeoatmospheric carbon dioxide concentration in the geological past? Philosophical Transactions Biological Sciences, 353, 83-96, https://doi.org/10.1098/rstb.1998.0193, 1998.

McElwain, J.C., Chaloner, W.G.: Stomatal density and index of fossil plants track atmospheric carbon dioxide in the Palaeozoic, Annals of Botany, 76, 389-395, https://doi.org/10.1006/anbo.1995.1112, 1995.

Mcelwain, J.C., Chaloner, W.G.: The Fossil Cuticle as a Skeletal Record of Environmental Change, Palaios, 11, 376-388, https://doi.org/10.2307/3515247, 1996.

Meissner, P., Mutterlose, J., Bodin, S.: Latitudinal temperature trends in the northern hemisphere 
during the Early Cretaceous (Valanginian-Hauterivian), Palaeogeography,

Palaeoclimatology, Palaeoecology, 424, 17-39,

https://doi.org/10.1016/j.palaeo.2015.02.003, 2015.

Miller, C.N.: Mesozoic conifers, The Botanical Review, 43(2), 217-280, 1977.

Möller, C., Bornemann A., Mutterlose J.: Climate and paleoceanography controlled size variations of calcareous nannofossils during the Valanginian Weissert Event (Early Cretaceous), Marine Micropaleontology, 157, 101875, https://doi.org/10.1016/j.marmicro.2020.101875, 2020.

OKUBO, A., KIMURA, T.: Cupressinocladus obatae, sp. nov., from the Lower Cretaceous Choshi Group, in the Outer Zone of Japan, Bulletin of the National Science Museum, Series C, 17(3), 91-109, 1991.

O'Reilly, J.E., Reis, M. dos, Donoghue, P.C.J.: Dating tips for divergence-time estimation, Trends in Genetics, 31 (11), 637-650, https://doi.org/10.1016/j.tig.2015.08.001, 2015.

Passalia, M.G.: Cretaceous $p \mathrm{CO}_{2}$ estimation from stomatal frequency analysis of gymnosperm leaves of Patagonia, Argentina, Palaeogeography, Palaeoclimatology, Palaeoecology, 273, 17-24, https://doi.org/10.1016/j.palaeo.2008.11.010, 2009.

Pearson, P.N., Palmer, M.R.: Atmospheric carbon dioxide concentrations over the past 60 million years, Nature, 406, 695, 2000.

Podlaha, O.G., Mutterlose, J., Veizer, J.: Preservation of $\delta^{18} \mathrm{O}$ and $\delta^{13} \mathrm{C}$ in belemnite rostra from the Jurassic/ Early Cretaceous successions, American Journal of Science, 324-347, https://doi.org/10.2475/ajs.298.4.324, 1998.

Price, G.D., Janssen, N.M.M., Martinez, M., Company, M., Vandevelde, J.H., Grimes, S.T.: A high-resolution belemnite geochemical analysis of Early Cretaceous (ValanginianHauterivian) environmental and climatic perturbations, Geochemistry, Geophysics, Geosystems, 19, 3832-3843, https://doi.org/10.1029/2018GC007676, 2018.

Price, G.D., Mutterlose, J.: Isotopic signals from late Jurassic-early Cretaceous (VolgianValanginian) sub-Arctic belemnites, Yatria River, Western Siberia, J. Geol. Soc., 161, 959-968, https://doi.org/10.1144/0016-764903-169, 2004.

Quan, C., Sun, C., Sun, Y., Sun, G.: High resolution estimates of paleo- $\mathrm{CO}_{2}$ levels through the Campanian (Late Cretaceous) based on Ginkgo cuticles, Cretaceous Research, 30, 424428, https://doi.org/10.1016/j.cretres.2008.08.004, 2009.

Reichgelt, T., D'Andrea, W.J.: Plant carbon assimilation rates in atmospheric $\mathrm{CO}_{2}$ reconstructions, New Phytologist, 223, 1844-1855, https://doi.org/10.1111/nph.15914, 2019.

Ren, D., Hong, Y.: Origin of angiosperms based on the flower-loving Brachycera fossils, Acta Zootaxonomica Sinica, 23, 212-221, 1998 (in Chinese with English abstract).

Retallack, G.J.: A 300-million-year record of atmospheric carbon dioxide from fossil plant cuticles, Nature, 411, 287, 2001.

Retallack, G.J.: Pedogenic carbonate proxies for amount and seasonality of precipitation in paleosols, Geology, 33, 333-336, https://doi.org/10.1130/G21263.1, 2005.

Retallack, G.J.: Refining a pedogenic-carbonate $\mathrm{CO}_{2}$ paleobarometer to quantify a middle Miocene greenhouse spike, Palaeogeography, Palaeoclimatology, Palaeoecology, 281(12), 57-65, https://doi.org/10.1016/j.palaeo.2009.07.011, 2009a.

Retallack, G.J.: Greenhouse crises of the past 300 million years, Geological Society of America Bulletin, 121, 1441-1455, https://doi.org/10.1130/B26341.1, $2009 \mathrm{~b}$. 
Robinson, S.A., Andrews, J.E., Hesselbo, S.P., Radley, J.D., Dennis, P.F., Harding, I.C., Allen, P.: Atmospheric $p \mathrm{CO}_{2}$ and depositional environment from stable-isotope geochemistry of calcrete nodules (Barremian, Lower Cretaceous, Wealden Beds, England), J. Geol. Soc., 159, 215-224, https://doi.org/10.1144/0016-764901-015, 2002.

Royer, D.L.: $\mathrm{CO}_{2}$-forced climate thresholds during the Phanerozoic, Geochim. Cosmochim. Acta, 70, 5665-5675, https://doi.org/10.1016/j.gca.2005.11.031, 2006.

Royer, D.L., Moynihan, K.M., McKee, M.L., Londoño, L., Franks, P.J.: Sensitivity of a leaf gasexchange model for estimating paleoatmospheric $\mathrm{CO}_{2}$ concentration, Climate of the Past, 15, 795-809, https://doi.org/10.5194/cp-15-795-2019, 2019.

Schubert, B.A., Jahren, A.H.: The effect of atmospheric $\mathrm{CO}_{2}$ concentration on carbon isotope fractionation in $\mathrm{C}_{3}$ land plants, Geochim. Cosmochim. Acta, 96, 29-43, https://doi.org/10.1016/j.gca.2012.08.003, 2012.

Schubert, B.A., Jahren, A.H.: Global increase in plant carbon isotope fractionation following the Last Glacial Maximum caused by increase in atmospheric $p \mathrm{CO}_{2}$, Geology, 43 (5), 435438, https://doi.org/10.1130/G36467.1, 2015.

Shi, G.L., Zhou, Z.Y., Xie, Z.M.; Cupressus foliage shoots and associated seed cones from the Oligocene Ningming Formation of Guangxi, South China, Review of Palaeobotany and Palynology, 166(3), 325-334, https://doi.org/10.1016/j.revpalbo.2011.06.005, 2011.

Skelton, P.W., Spicer, R.A., Kelley, S.P., Gilmour, I.: The Cretaceous World, 2003.

Srinivasan, V.: Two new species of the conifer Glenrosa from the Lower Cretaceous of North America, Review of Palaeobotany and Palynology, 72, 245-255, https://doi.org/10.1016/0034-6667(92)90029-G, 1992.

Srinivasan, V.: Conifers from the Puddledock locality (Potomac Group, Early Cretaceous) in eastern North America, Review of Palaeobotany and Palynology, 89(3-4), 257-286, https://doi.org/10.1016/0034-6667(95)00010-8, 1995.

Steinthorsdottir, M., Jeram, A.J., McElwain, J.C.: Extremely elevated $\mathrm{CO}_{2}$ concentrations at the Triassic/Jurassic boundary, Palaeogeography, Palaeoclimatology, Palaeoecology, 308, 418-432, https://doi.org/10.1016/j.palaeo.2011.05.050, 2011.

Steinthorsdottir, M., Vajda, V.: Early Jurassic (late Pliensbachian) $\mathrm{CO}_{2}$ concentrations based on stomatal analysis of fossil conifer leaves from eastern Australia, Gondwana Res., 27, 932-939, https://doi.org/10.1016/j.gr.2013.08.021, 2015.

Steinthorsdottir, M., Wohlfarth, B., Kylander, M.E., Blaauw, M., Reimer, P.J.: Stomatal proxy record of $\mathrm{CO}_{2}$ concentrations from the last termination suggests an important role for $\mathrm{CO}_{2}$ at climate change transitions, Quat. Sci. Rev., 68, 43-58, https://doi.org/10.1016/j.gr.2013.08.021, 2013.

Sun, B.N., Xiao, L., Xie, S.P., Deng, S.H., Wang, Y.D., Jia, H., Turner, S.: Quantitative analysis of paleoatmospheric $\mathrm{CO}_{2}$ level based on stomatal characters of fossil Ginkgo from Jurassic to Cretaceous in China, Acta Geol. Sin., 81, 931-939, https://doi.org/10.1111/j.1755-6724.2007.tb01016.x, 2007.

Sun, Y.W., Li, X., Zhao, G.W., Liu, H., Zhang, Y.L.: Aptian and Albian atmospheric $\mathrm{CO}_{2}$ changes during oceanic anoxic events: evidence from fossil Ginkgo cuticles in Jilin Province, Northeast China, Cretaceous Research, 62, 130-141, https://doi.org/10.1016/j.cretres.2015.12.007, 2016.

Tajika, E.: Carbon cycle and climate change during the Cretaceous inferred from a 
biogeochemical carbon cycle model, Island Arc, 8, 293-303, https://doi.org/10.1046/j.1440-1738.1999.00238.x, 1999.

Wallmann, K.: Controls on the Cretaceous and Cenozoic evolution of seawatercomposition, atmospheric $\mathrm{CO}_{2}$ and climate, Geochim. Cosmochim. Acta, 65, 3005-3025, https://doi.org/10.1016/S0016-7037(01)00638-X, 2001.

Wan, C.B., Wang, D.H., Zhu, Z.P., Quan, C.: Trend of Santonian (Late Cretaceous) atmospheric $\mathrm{CO}_{2}$ and global mean land surface temperature: evidence from plant fossils, Earth Sci., 54, 1338-1345, doi: 10.1007/s11430-011-4267-1, 2011.

Wang, Y.D., Huang, C.M., Sun, B.N., Quan, C., Wu, J.Y., Lin, Z.C.: Paleo-CO $\mathrm{CO}_{2}$ variation trends and the Cretaceous greenhouse climate, Earth-Science Reviews, 129, 136-147, https://doi.org/10.1016/j.earscirev.2013.11.001, 2014.

Watson, J.: The Cheirolepidiaceae. In: Origin and Evolution of Gymnosperms, edited by: Beck, C.B., Columbia University Press, New York, pp. 382-447, 1988.

Watson, J., Fisher, H.L.: A new conifer genus from the Lower Cretaceous Glen Rose Formation, Texas, Palaeontology, 77, 719-727, 1984.

Weissert, H., Erba, E.: Volcanism, $\mathrm{CO}_{2}$ and palaeoclimate: a Late Jurassic-Early Cretaceous carbon and oxygen isotope record, Journal of the Geological Society, 161, 695-702, https://doi.org/10.1144/0016-764903-087, 2004.

Wortmann, U.G., Weissert, H.: Tying platform drowning to perturbations of the global carbon cycle with a $\delta^{13} \mathrm{C}_{\mathrm{Org}}$-curve from the Valanginian of DSDP Site 416, Terra Nova, 12, 289-294, https://doi.org/10.1046/j.1365-3121.2000.00312.x, 2000.

Xie, S.W., Wu, Y.B., Zhang, Z.M., Qin, Y.C., Liu, X.C., Wang, H., Qin, Z.W., Liu, Q., Yang, S.H.: U-Pb ages and trace elements of detrital zircons from Early Cretaceous sedimentary rocks in the Jiaolai Basin, north margin of the Sulu UHP terrane: Provenances and tectonic implications, Lithos, 154, 346-360, https://doi.org/10.1016/j.lithos.2012.08.002, 2012.

Zhang, J.F., Rasnitsyn, A.P.: New extinct taxa of Pelecinidae sensu lato (Hymenoptera: Proctotrupoidea) in the Laiyang Formation, Shandong, China, Cretaceous Research, 27 (5), 684-688, https://doi.org/10.1016/j.cretres.2006.03.001, 2006.

Zhang, Y.Q., Dong, S.W., Shi, W.: Cretaceous deformation history of the middle Tan2Lu fault zone in Shandong Province, Eastern China, Tectonophysics, 363 (324), 243-258, https://doi.org/10.1016/S0040-1951(03)00039-8, 2003.

Zhang, Y.Q., Li, J.L., Zhang, T., Dong, S.W., Yuan, J.Y.: Cretaceous to Paleocene TectonoeSedimentary Evolution of the Jiaolai Basin and the Contiguous Areas of the Shandong Peninsula (North China) and Its Geodynamic Implications, Acta Geologica Sinica, 82 (9), 1229-1257, 2008 (in Chinese with English abstract).

Zhou, N., Wang, Y.D., Ya, L., Porter, A.S., Kürschner, W.M., Li, L.Q., Lu, N., McElwain, J.C.: An inter-comparison study of three stomatal-proxy methods for $\mathrm{CO}_{2}$ reconstruction applied to early jurassic ginkgoales plants, Palaeogeography, Palaeoclimatology, Palaeoecology, 542(15), 109547, https://doi.org/10.1016/j.palaeo.2019.109547, 2020. 